\title{
$\alpha$-Tocopherol at Nanomolar Concentration Protects Cortical Neurons against Oxidative Stress
}

\author{
Irina O. Zakharova ${ }^{1}$, Tatiana V. Sokolova ${ }^{1}$, Yulia A. Vlasova ${ }^{1,2}$, Liubov V. Bayunova ${ }^{1}$, \\ Maria P. Rychkova ${ }^{1}$ and Natalia F. Avrova ${ }^{1, *}$ \\ 1 Department of Molecular Endocrinology and Neurochemistry, I.M. Sechenov Institute of Evolutionary \\ Physiology and Biochemistry of the Russian Academy of Sciences, Thorez avenue, 44, \\ Saint-Petersburg 194223, Russia; zakhar@iephb.ru (I.O.Z.); sokolt1956@mail.ru (T.V.S.); \\ yousia@mail.ru (Y.A.V.); bayunoval@mail.ru (L.V.B.); involved@mail.ru (M.P.R.) \\ 2 Preventive Medicine Department, Mechnikov North-West StateMedical University, Saint-Petersburg, \\ Kirochnaya ul. 41, Saint-Petersburg 191015, Russia \\ * Correspondence: avrova@iephb.ru; Tel.: +7-812-552-8035 \\ Academic Editor: Katalin Prokai-Tatrai \\ Received: 28 September 2016; Accepted: 14 January 2017; Published: 21 January 2017
}

\begin{abstract}
The aim of the present work is to study the mechanism of the $\alpha$-tocopherol $(\alpha$-T) protective action at nanomolar and micromolar concentrations against $\mathrm{H}_{2} \mathrm{O}_{2}$-induced brain cortical neuron death. The mechanism of $\alpha$-T action on neurons at its nanomolar concentrations characteristic for brain extracellular space has not been practically studied yet. Preincubation with nanomolar and micromolar $\alpha$-T for $18 \mathrm{~h}$ was found to increase the viability of cortical neurons exposed to $\mathrm{H}_{2} \mathrm{O}_{2} ; \alpha-\mathrm{T}$ effect was concentration-dependent in the nanomolar range. However, preincubation with nanomolar $\alpha-\mathrm{T}$ for $30 \mathrm{~min}$ was not effective. Nanomolar and micromolar $\alpha$-T decreased the reactive oxygen species accumulation induced in cortical neurons by the prooxidant. Using immunoblotting it was shown that preincubation with $\alpha$-T at nanomolar and micromolar concentrations for $18 \mathrm{~h}$ prevented Akt inactivation and decreased PKC $\delta$ activation induced in cortical neurons by $\mathrm{H}_{2} \mathrm{O}_{2} . \alpha$-T prevented the ERK1/ 2 sustained activation during $24 \mathrm{~h}$ caused by $\mathrm{H}_{2} \mathrm{O}_{2} \cdot \alpha-\mathrm{T}$ at nanomolar and micromolar concentrations prevented a great increase of the proapoptotic to antiapoptotic proteins (Bax/Bcl-2) ratio, elicited by neuron exposure to $\mathrm{H}_{2} \mathrm{O}_{2}$. The similar neuron protection mechanism by nanomolar and micromolar $\alpha$-T suggests that a "more is better" approach to patients' supplementation with vitamin $\mathrm{E}$ or $\alpha-\mathrm{T}$ is not reasonable.
\end{abstract}

Keywords: brain cortical neurons; $\mathrm{H}_{2} \mathrm{O}_{2} ; \alpha$-tocopherol; nanomolar and micromolar concentrations; viability; reactive oxygen species; ERK1/2; Akt; protein kinase $\mathrm{C} \delta$; Bax/Bcl-2 ratio

\section{Introduction}

The development of oxidative stress is one of the main causes of brain nerve cell damage and death in neurodegenerative and ischemic diseases, such as Parkinson's and Alzheimer's diseases or brain insult. These widespread diseases result in cognitive dysfunction, disablement and death for elderly people. For many years it was hoped that vitamin E might be used as a remedy for various diseases concerned with pathological accumulation of reactive oxygen species (ROS) in the cells of various organs. However, analysis of the results of clinical trials revealed the unfavorable effect of administering high doses of vitamin $\mathrm{E}$. Thus, analysis of the published results of randomized clinical trials (more than 100,000 observations) of vitamin E administration to people with various diseases showed that the all-cause mortality for patients and people in risk groups who received high doses of vitamin $E$ in their diet was higher than for those who received a placebo [1-3]. The main and most active component of vitamin $\mathrm{E}$ in various organs in humans and animals is $\alpha$-tocopherol $(\alpha$-T). Specific 
$\alpha-T$ transfer and binding proteins prevent it from metabolic degradation. The above-mentioned clinical trial results show the need for studying the mechanism of action of $\alpha$-T and vitamin $E$ other components at their physiological concentrations, at which they exert their effects on the cells of various organs and on various cells of the same organ in vivo, and which may differ from their effect at high pharmacological concentrations [4]. Thus, it was shown that ischemic stroke-induced brain injury was exacerbated in the presence of supraphysiologic brain $\alpha$-T level [4].

The delivery of vitamin E components from the blood to the cerebrospinal fluid takes place across the blood-brain barrier. $\alpha$-T is the main vitamin $\mathrm{E}$ component. In cerebrospinal fluid its concentration was found to be $42.1 \pm 17 \mathrm{nM}$, while the concentration of other vitamin E components was much lower-for example, the $\gamma$-tocopherol concentration was found to be $5.9 \pm 2.8 \mathrm{nM}$ [5]. Similar data were obtained in other studies (see, for example, [6]).

Various vitamin $\mathrm{E}$ isoforms $(\alpha-, \beta-, \gamma-$ and $\delta$-tocopherols and tocotrienols) not only possess a radical scavenging activity, but also modulate the activity of a large number of signaling pathways; in most cases the data were originally obtained using non-neural cells. Thus, $\alpha-T$ was shown to inhibit the activity of the protein kinase C (PKC), the extracellular signal-regulated $1 / 2$ protein kinase (ERK1/2) and the phosphatidylinositol 3-kinase (PI 3-kinase)/Akt pathway, and to activate protein phosphatases, especially protein phosphatase $2 \mathrm{~A}$ and lipid phosphatase, e.g., dual specificity phospatase PTEN (phosphatase and tensin homologue), as well as to modulate the activity of cyclooxygenase 1/2, lipoxygenases, NADPH oxidase and the function of ion channels [6-9]. In contrast to "non-neural" cells, $\alpha$-T was found to activate basal ERK1/2 and Akt in brain cortical neurons [10]. These effects of $\alpha$-T are sometimes called the "non-antioxidant functions of $\alpha-T$ ", though the signaling pathways modulation may lead to a decrease in the ROS accumulation in cells. Various components of vitamin $\mathrm{E}$ differ from one another much more in their modulation of signal transduction pathways than in the level of their scavenging activity $[7,8]$.

The majority of studies of the $\alpha$-T protective effect on nerve cells is performed using micromolar concentrations. At the same time, nanomolar $\alpha$-tocotrienol was found to increase the viability of both hippocampal neurons and cells of the HT4 hippocampal cell line exposed to glutamate; its effect was shown to depend on the inhibition of 12-lipoxygenase and phospholipase $A_{2}$ [11,12]. Data on the protective effect of $\alpha$-T at nanomolar concentrations on nerve cells and cells of neuronal cell lines are not abundant $[10,13,14]$. The protective effect of $250 \mathrm{nM} \alpha$-T against $10 \mathrm{mM}$ glutamate-induced death of immature brain cortical neurons was shown to be much less pronounced than the protective effect of $2.5 \mu \mathrm{M} \alpha-\mathrm{T}$ [13]. It was also shown [10,14] that long preincubation (18-24 h) with $\alpha-\mathrm{T}$ at nanomolar concentrations increased its protective effect in rat brain cortical neurons and PC12 cells. The protective effect of nanomolar $\alpha$-T against the $\mathrm{H}_{2} \mathrm{O}_{2}$-induced death of brain cortical neurons [10] or PC12 cells [14] was comparable with the protective effect of micromolar $\alpha$-T after preincubation for $18-24 \mathrm{~h}$.

According to Numakawa and co-authors, $\alpha$-T at nanomolar concentrations was shown to increase the activity of basal ERK1/2 and protein kinase B (Akt), as well as the Bcl-2 level in cortical neurons [10]. However, neither this nor other studies have shown how $\mathrm{H}_{2} \mathrm{O}_{2}$ modulates the activity of ERK1/2 and Akt, and how $\alpha$-T diminishes or abolishes the toxic effects of $\mathrm{H}_{2} \mathrm{O}_{2}$ in the nerve cells.

The aim of the present work is to study the effect of $\mathrm{H}_{2} \mathrm{O}_{2}$ and long $(18 \mathrm{~h})$ preincubation with $\alpha$-T at nanomolar and micromolar concentrations on the viability of immature rat brain cortical neurons in culture, on the activity of protein kinases and the ratio of pro- to antiapoptotic proteins in these neurons. It was found that long $(18 \mathrm{~h})$ preincubation of cortical neurons with $\alpha$-T at nanomolar or micromolar concentrations prevented the inactivation of Akt and pronounced decrease of $\mathrm{Bcl}-2$ level leading to an increase of the proapoptotic to antiapoptotic protein ratio (Bax/Bcl-2) in neurons induced by cell exposure to $\mathrm{H}_{2} \mathrm{O}_{2}$. Nanomolar and micromolar $\alpha$-T also diminished the activation of PKC $\delta$ induced by $\mathrm{H}_{2} \mathrm{O}_{2}$ and the time of maximal activation of ERK1/2 by this prooxidant in brain cortical neurons. 


\section{Results and Discussion}

\section{1. $\alpha$-T and the Viability and Function of Nerve Cells}

A vitamin $\mathrm{E}$ or $\alpha$-T deficiency leads to an abnormal functioning of the brain. Thus, mutations in the $\alpha$-T transfer protein gene result in a disease called "ataxia with vitamin E deficiency" [15], vitamin E supplementation to such patients' diet gives good results [15]. However, administration of vitamin E to patients with neurodegenerative diseases was not helpful. It was even suggested that it might be "time to stop feeding vitamin E to dementia patients" [16]. There are data showing that the mechanism of $\alpha$-T effect on nerve cells metabolism, viability and functioning is rather complicated; and appears not to be exclusively limited to its scavenging activity. Thus, the long-term (up to 46 weeks) maintenance of mice on a diet with a deficit of vitamin $E$ and the use of mice with targeted disruption of the $\alpha$-T transfer protein gene (which mutations lead to the above-mentioned hereditary ataxia with vitamin E deficiency in humans) resulted in a large decrease of the $\alpha$-T content in the brain and other organs [17]. However, the intensity of the lipid peroxidation processes in the brain of these mice was not increased; on the contrary, it was markedly diminished, and exposure of the brain tissue to $\alpha$-T greatly increased ROS production and accumulation [17].

The long pre-treatment of hippocampal neurons with $1-2.5 \mu \mathrm{M} \alpha-\mathrm{T}$ prior to the induction of oxidative stress provided a long-lasting protection via genomic activation, which was in contrast with the transient effect of $\alpha$-T on neuron viability based on its radical scavenging activity [18,19].

The effects of $\alpha-\mathrm{T}$ and other vitamin $\mathrm{E}$ components at their physiological nanomolar concentrations [5,6] characteristic for cerebrospinal fluid and brain extracellular space (at which they act on various brain cells in vivo) may differ from their effects at much higher pharmacological concentrations [4,7], especially in the case of long-term administration to humans or animals. Thus, it was shown that excessive $\alpha$-T in the brain exacerbated microglial activation and brain injury caused by acute ischemic stroke in mice [4].

\subsection{The Dosage and Duration of Treatment with $\alpha$-T Govern Its Neuroprotective Effect}

If neurons were preincubated with $\alpha$-T for $18 \mathrm{~h}$ and then exposed to $0.2 \mathrm{mM} \mathrm{H}_{2} \mathrm{O}_{2}$, the protective effect of $\alpha$-T at $100 \mathrm{nM}$ and $100 \mu \mathrm{M}$ concentrations on neurons in complete incubation medium containing serum was similar and significant (Figure 1B). Preincubation with $10 \mathrm{nM} \alpha-\mathrm{T}$ for $18 \mathrm{~h}$ also increased viability of brain cortical neurons, but to a lesser extent than preincubation with $\alpha$-T at $100 \mathrm{nM}$ and higher concentration (Figure 1B). The data obtained in the experiments were expressed as $\alpha$-T rescue rates (Table 1 ).

We also studied the correlation between $\alpha$-T concentrations (using a logarithmic scale) and its rescue rates at these concentrations. The most well-defined positive correlation $\left(n=28, r^{2}=0.53\right.$, $r=0.728, p<0.0001$ ) between these two variables was achieved when the effects of $10^{-9}, 10^{-8}$ and $10^{-7} \mathrm{M} \alpha-\mathrm{T}(1,10$ and $100 \mathrm{nM} \alpha-\mathrm{T})$ were compared. A less pronounced positive correlation between these two variables $\left(n=53, r^{2}=0.389, r=0.62, p<0.001\right)$ was revealed when comparing the rescue rates characteristic for all the concentrations studied and presented in Table 1 . There is no correlation at all between $\alpha$-T concentrations of $10^{-7} \mathrm{M}$ and higher and $\alpha$-T rescue rates at these concentrations $\left(n=36, r^{2}=0.04, r=0.19, p=0.26\right)$. This can clearly be seen on the logarithmic scale graphs.

The data presented in Table 1 as well as the data about correlation between $\alpha$-T concentrations and its rescue rates at these concentrations provide evidence that the protective effect of $\alpha$-T on brain cortical neurons against $\mathrm{H}_{2} \mathrm{O}_{2}$-induced death was concentration-dependent in the range 1-100 nM $(1 \mathrm{nM}<10 \mathrm{nM}<100 \mathrm{nM})$ if preincubation was performed for $18 \mathrm{~h}$. Preincubation with $1 \mathrm{nM} \alpha-\mathrm{T}$ did not significantly protect brain cortical neurons against $\mathrm{H}_{2} \mathrm{O}_{2}$-induced toxicity; the rescue rate of $10 \mathrm{nM}$ $\alpha$-T was significantly higher than that of $1 \mathrm{nM} \alpha-\mathrm{T}$ and its protective effect was significant. The $\alpha-\mathrm{T}$ rescue rates at $100 \mathrm{nM}, 1 \mu \mathrm{M}, 10 \mu \mathrm{M}$ and $100 \mu \mathrm{M}$ concentrations did not significantly differ from one another, but were higher than the rescue rate of $\alpha$-T at $10 \mathrm{nM}$ concentration (Table 1). 

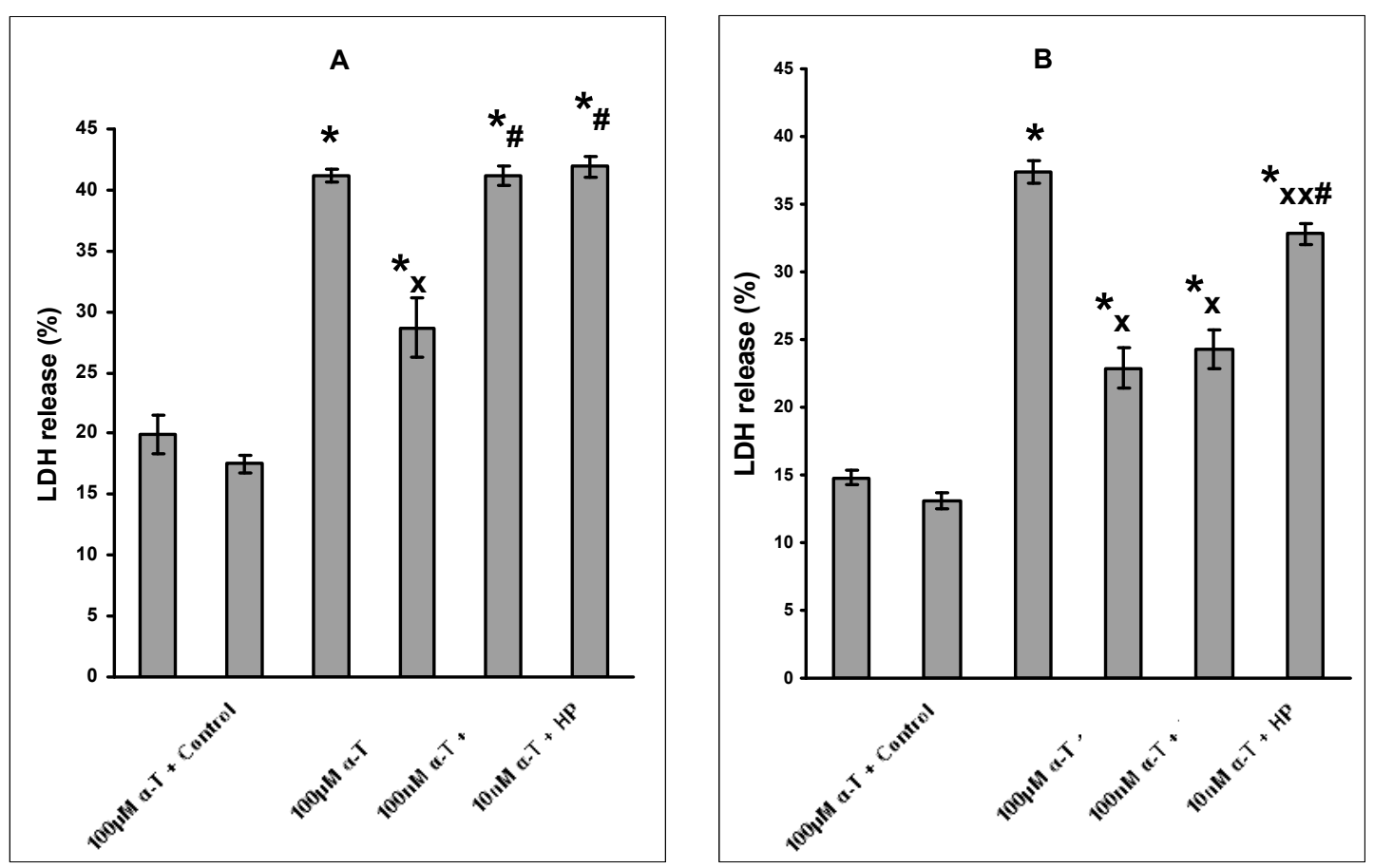

Figure 1. Shows that preincubation of immature brain cortical neurons with $\alpha$-tocopherol $(\alpha-\mathrm{T})$ at nanomolar concentrations for $0.5 \mathrm{~h}$ prior to exposure of the cells to $0.2 \mathrm{mM} \mathrm{H}_{2} \mathrm{O}_{2}$ for $24 \mathrm{~h}$ did not increase the viability of brain cortical neurons (A); while preincubation with 10 and $100 \mathrm{nM} \alpha-\mathrm{T}$ for $18 \mathrm{~h}$ prior to exposure of the neurons to $0.2 \mathrm{mM} \mathrm{H}_{2} \mathrm{O}_{2}$ for $24 \mathrm{~h}$ caused a pronounced increase in cortical neuron viability (B). $\mathrm{H}_{2} \mathrm{O}_{2}$ is designated as $\mathrm{HP}$ in the figure. Lactate dehydrogenase (LDH) method was used to determine neuron viability. The data bars (from the left to the right) in (A,B) show: (1) control values of LDH release from neurons; (2) control values of LDH release after incubation of the neurons with $100 \mu \mathrm{M} \alpha$-T for $30 \mathrm{~min}(\mathbf{A})$ or for $18 \mathrm{~h}(\mathbf{B})$; (3) LDH release after neuron exposure to $\mathrm{H}_{2} \mathrm{O}_{2}$; (4) $\mathrm{LDH}$ release after preincubation of the neurons with $100 \mu \mathrm{M} \alpha$-T prior to the cell exposure to $\mathrm{H}_{2} \mathrm{O}_{2}$;

(5) $\mathrm{LDH}$ release after preincubation of the neurons with $100 \mathrm{nM} \alpha$-T prior to the cell exposure to $\mathrm{H}_{2} \mathrm{O}_{2}$;

(6) $\mathrm{LDH}$ release after preincubation of the neurons with $10 \mathrm{nM} \alpha$-T prior to the cell exposure to $\mathrm{H}_{2} \mathrm{O}_{2}$. The results of one typical experiment from 9 experiments performed are shown as means \pm SEM from 2-3 determinations in parallel samples. One way ANOVA followed by Tukey's multiple comparison test was used to assess the significance of the differences between various groups of data. The differences were found to be significant: ${ }^{*}$ - compared to control values, $p<0.01 ;{ }^{\mathrm{x}}$ and ${ }^{\mathrm{xx}}$-compared to the effect of $\mathrm{H}_{2} \mathrm{O}_{2}$ alone; ${ }^{\mathrm{x}} p<0.01,{ }^{\mathrm{xx}} p<0.05$, \#_ compared to the effect of $\alpha$-T higher concentrations, $p<0.01$.

Table 1. Shows the protective effect of preincubation with $\alpha-\mathrm{T}$ for $18 \mathrm{~h}$ prior to brain cortical neuron exposure to $0.2 \mathrm{mM} \mathrm{H}_{2} \mathrm{O}_{2}$ for $24 \mathrm{~h}$ expressed as rescue rates of $\alpha$-T. Cell viability was assessed by the LDH method. The data are means \pm SEM from 7-9 experiments. The difference in the LDH activity released from cortical neurons exposed to $\mathrm{H}_{2} \mathrm{O}_{2}$ in the absence and presence of $\alpha$-T was determined. The ratio of this difference to the increase of LDH activity released from neurons to the medium in the presence of $\mathrm{H}_{2} \mathrm{O}_{2}$ alone (taken as $100 \%$ ) corresponded to the rescue rates of $\alpha$-T against $\mathrm{H}_{2} \mathrm{O}_{2}$-induced cell death. The formula is ([LDH release in $\mathrm{H}_{2} \mathrm{O}_{2}-\mathrm{LDH}$ release in $\mathrm{H}_{2} \mathrm{O}_{2}$ and $\alpha$-T]/[LDH release in $\mathrm{H}_{2} \mathrm{O}_{2}-\mathrm{LDH}$ release in control]) $\times 100$. In this table: *- the protective effect of $\alpha$-T is significant, $p<0.01 ;{ }^{\mathbf{x}}$ and ${ }^{\#}$ - the differences are significant according to Student's $t$ test as compared to the effect of $\alpha$-T at lower concentrations, ${ }^{\mathbf{x}} p<0.02,{ }^{*} p<0.01$.

\begin{tabular}{|c|c|c|c|c|c|c|}
\hline$\alpha$-T Concentration & $100 \mu \mathrm{M} \alpha-\mathrm{T}$ & $10 \mu \mathrm{M} \alpha-\mathrm{T}$ & $1 \mu \mathrm{M} \alpha-\mathrm{T}$ & $100 \mathrm{nM} \alpha-\mathrm{T}$ & $10 \mathrm{nM} \alpha-\mathrm{T}$ & $1 \mathrm{nM} \alpha-\mathrm{T}$ \\
\hline Rescue rates $(\%)$ & $64.3 \pm 7.2 *$ & $67.4 \pm 11.9^{*}$ & $60.0 \pm 11.4^{*}$ & $52.5 \pm 7.4^{* x}$ & $27.3 \pm 5.1^{* \#}$ & $5.1 \pm 2.9$ \\
\hline
\end{tabular}


Previously, we have shown [14] that the protective effect of $\alpha$-T against $\mathrm{H}_{2} \mathrm{O}_{2}$-induced PC12 cell death was also higher the higher was the $\alpha$-T concentration in the nanomolar range $(1 \mathrm{nM}<10 \mathrm{nM}<100 \mathrm{nM})$. Numakawa and co-authors were the first to show the protective effect of nanomolar $\alpha-T$, but did not reveal its dependence on the $\alpha$-T concentration [10].

Another piece of evidence of the protective role that preincubation of neuronal cells with $\alpha$-T at nanomolar concentrations plays was provided by studies of $\alpha$-T ability to increase viability of PC12 cells exposed to eleostaric acid, which caused increase in ROS production and apoptotic cell death [20].

2.3. The Protective Effect of Preincubation with $\alpha$-T for $18 \mathrm{~h}$ against $\mathrm{H}_{2} \mathrm{O}_{2}$-Induced Death of Brain Cortical Neurons Is Diminished or Abolished in the Presence of Inhibitors of PI 3-Kinase, MEK1/2 and PKC $\delta$

The data obtained are presented in Table 2.

Table 2. Shows that the rescue rates of $\alpha$-T against $\mathrm{H}_{2} \mathrm{O}_{2}$-induced brain cortical neuron death were significantly lower in the presence of an inhibitor of PI 3-kinase (LY294002), an inhibitor of MEK1/2 (SL327) and an inhibitor of PKC $\delta$ (rottlerin) than in their absence in the incubation medium. Cell viability was assessed by the LDH method. The data are means \pm SEM from 5-6 experiments. Preincubation with protein kinase inhibitors was performed for $0.5 \mathrm{~h}$, then $\alpha-\mathrm{T}$ was added for $18 \mathrm{~h}$ before brain cortical neuron exposure to $0.2 \mathrm{mM} \mathrm{H}_{2} \mathrm{O}_{2}$ for $24 \mathrm{~h}$. In this table: ** and *-the protective effect of $\alpha$-T is significant, ${ }^{* *} p<0.02,{ }^{*} p<0.05{ }^{x}$ and ${ }^{\#}$-the differences are significant as compared to the effect of $\alpha$-T in the absence of inhibitors by paired Student's $t$-test, ${ }^{\mathbf{x}} p<0.02,{ }^{\#} p<0.05$.

\begin{tabular}{cccc}
\hline Sample & Rescue Rates of $\alpha$-T, $\%$ & Sample & Rescue Rates of $\alpha$-T, $\%$ \\
\hline $100 \mathrm{nM} \alpha-\mathrm{T}$ & $52.4 \pm 13.1^{* *}$ & $100 \mu \mathrm{M} \alpha-\mathrm{T}$ & $63.35 \pm 12.6^{* *}$ \\
$100 \mathrm{nM} \alpha-\mathrm{T}+10 \mu \mathrm{M}$ SL327 & $31.35 \pm 11.1^{*, \#}$ & $100 \mu \mathrm{M} \alpha-\mathrm{T}+10 \mu \mathrm{M}$ SL327 & $36.9 \pm 12.3^{*}$ \\
$100 \mathrm{nM} \alpha-\mathrm{T}+50 \mu \mathrm{M}$ LY294002 & $10.1 \pm 4.6^{*}$ & $100 \mu \mathrm{M} \alpha-\mathrm{T}+50 \mu \mathrm{M}$ LY294002 & $27.6 \pm 14.7^{\#}$ \\
$100 \mathrm{nM} \alpha-\mathrm{T}$ & $50.0 \pm 7.5^{* *}$ & $100 \mu \mathrm{M} \alpha-\mathrm{T}$ & $52.2 \pm 6.4^{* *}$ \\
$100 \mathrm{nM} \alpha-\mathrm{T}+5 \mu \mathrm{M}$ rottlerin & $20.9 \pm 4.6^{* *, \mathrm{x}}$ & $100 \mu \mathrm{M} \alpha-\mathrm{T}+5 \mu \mathrm{M}$ rottlerin & $33.6 \pm 4.8^{* *, x}$ \\
\hline
\end{tabular}

The rescue rates were calculated either in the absence of the inhibitor in all samples or in the presence of the same inhibitor in all samples. In most—but not in all—experiments, the LDH release was higher in presence of both $\mathrm{H}_{2} \mathrm{O}_{2}$ and one of the inhibitors than in presence of $\mathrm{H}_{2} \mathrm{O}_{2}$ alone, but the difference was not significant. If the effect of $\mathrm{H}_{2} \mathrm{O}_{2}$ alone is taken for $100 \%$, the combined effect of $\mathrm{H}_{2} \mathrm{O}_{2}$ and LY294002, SL327 or rottlerin is respectively $122.5 \% \pm 10.1 \%, 115 \% \pm 9.6 \%$ or $116 \% \pm 7 \%$ $(p>0.05)$.

In presence of the MEK1/2/ERK1/2 and the PI 3-kinase/Akt pathways inhibitors and of the PKC $\delta$ inhibitor, the ability of $100 \mathrm{nM}$ and $100 \mu \mathrm{M} \alpha$-T to rescue neurons from $\mathrm{H}_{2} \mathrm{O}_{2}$-induced death was markedly and significantly diminished or became insignificant (Table 2).

However, such data should be interpreted with caution. For example, rottlerin was shown not to be a specific inhibitor of PKC $\delta$; it inhibits or activates other metabolic processes in cells [21,22], including the modulation of some protein kinase activity, for example, $\mathrm{Ca}^{2+} /$ calmodulin-dependent protein kinase activity.

The protective effect of $\alpha$-T at nanomolar and micromolar concentrations against $\mathrm{H}_{2} \mathrm{O}_{2}$-induced PC12 cell death [14] was also shown to be markedly diminished in the presence of PI 3-kinase and MEK1/2 inhibitors if the cells were preincubated with $\alpha$-T for $18 \mathrm{~h}$.

2.4. $\alpha$-T at Micromolar and Nanomolar Concentrations Diminishes the Accumulation of ROS Induced in Brain Cortical Neurons by $\mathrm{H}_{2} \mathrm{O}_{2}$

The data showing that $\alpha$-T diminishes the accumulation of ROS in brain cortical neurons are presented in Figure 2. 


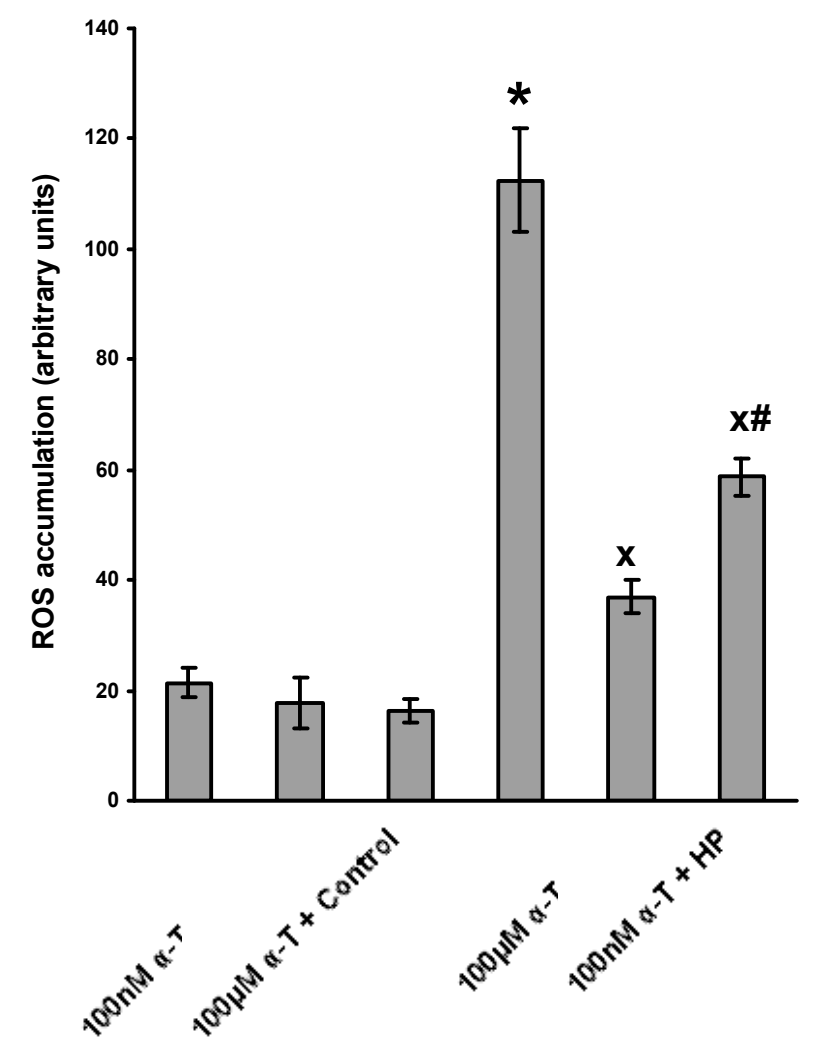

Figure 2. Shows that long preincubation with $\alpha$-tocopherol $(\alpha-\mathrm{T})$ at nanomolar and micromolar concentrations diminished ROS accumulation in brain cortical neuron elicited by $\mathrm{H}_{2} \mathrm{O}_{2}$ to a great extent. The neurons were preincubated with $\alpha$-T for $18 \mathrm{~h}$. Then the fluorescent dye dichlorodihydrofluorescein diacetate was added to the incubation medium to a final concentration of $25 \mu \mathrm{M}$ (see "Materials and Methods"). After $40 \mathrm{~min}$ incubation, the cells were exposed to $0.2 \mathrm{mM} \mathrm{H}_{2} \mathrm{O}_{2}$ for $4 \mathrm{~h} . \mathrm{H}_{2} \mathrm{O}_{2}$ in the Figure is designated as HP. The data bars (from the left to the right) show: (1) control values; (2) control values after incubation of the neurons with $100 \mathrm{nM} \alpha$-T; (3) control values after incubation of the neurons with $100 \mu \mathrm{M} \alpha$-T; (4) ROS accumulation (arbitrary units) after neuron exposure to $\mathrm{H}_{2} \mathrm{O}_{2}$; (5) ROS accumulation after preincubation of the neurons with $100 \mu \mathrm{M} \alpha-\mathrm{T}$ prior to the cell exposure to $\mathrm{H}_{2} \mathrm{O}_{2}$; (6) ROS accumulation after preincubation of the neurons with $100 \mathrm{nM} \alpha$-T prior to the cell exposure to $\mathrm{H}_{2} \mathrm{O}_{2}$. The results of one typical experiment are shown as means \pm SEM from 4-6 determinations in parallel samples. One-way ANOVA followed by Tukey's test for multiple comparison was used to assess significance of the differences between various groups of data. The differences were found to be significant: *-compared to control values; ${ }^{\mathrm{x}}$ - compared to the effect of $\mathrm{H}_{2} \mathrm{O}_{2}$ alone; ${ }^{\#}$ - compared to the effect of $100 \mu \mathrm{M} \alpha-\mathrm{T}(p<0.01$ in all cases).

The data obtained provide evidence that the average inhibition of $\mathrm{H}_{2} \mathrm{O}_{2}$-initiated ROS accumulation by preincubation with $100 \mu \mathrm{M}$ and $100 \mathrm{nM} \alpha-\mathrm{T}$ for $18 \mathrm{~h}$ was $75.9 \% \pm 3.1 \%$ and $54.8 \% \pm 7.1 \%$, respectively; the antioxidative effect of micromolar and nanomolar $\alpha$-T was highly significant $(p<0.001$ and $p<0.01$, respectively), the effect of $100 \mu \mathrm{M} \alpha$-T being more pronounced than the effect of $100 \mathrm{nM} \alpha$-T under the experimental conditions used $(p<0.05, n=4)$.

In another series of experiments we tried to study ROS accumulation in brain cortical neurons after their long preincubation with nanomolar and micromolar $\alpha$-T prior to long ( $24 \mathrm{~h}$ ) exposure to $0.2 \mathrm{mM} \mathrm{H}_{2} \mathrm{O}_{2}$. However, under such a long exposure to $\mathrm{H}_{2} \mathrm{O}_{2} \mathrm{ROS}$ accumulation was not significant in a large part of the experiments, so we failed to obtain reliable results. It appears that exposure to $0.2 \mathrm{mM} \mathrm{H}_{2} \mathrm{O}_{2}$ for $24 \mathrm{~h}$ is the optimal time to measure the viability of neurons, but not to assess the initial disturbances of the metabolic processes caused by this prooxidant in the nerve cells. 
If the neurons were preincubated with $\alpha$-T for $1.5 \mathrm{~h}$ and then exposed to $\mathrm{H}_{2} \mathrm{O}_{2}$ for $2 \mathrm{~h}, 100 \mu \mathrm{M}$ $\alpha$-T was found to reduce ROS accumulation almost to the control levels, while $100 \mathrm{nM} \alpha$-T inhibited $\mathrm{H}_{2} \mathrm{O}_{2}$-induced ROS accumulation by $47.4 \% \pm 1.5 \%(n=5)$.

We have previously [23] shown that the ability of 10 and $100 \mathrm{nM} \alpha$-T to decrease ROS accumulation initiated in $\mathrm{PC} 12$ cells by $\mathrm{H}_{2} \mathrm{O}_{2}$ was diminished or became insignificant in the presence of MEK1/2/ERK1/2 and PI 3-kinase/Akt pathways inhibitors (SL327 and LY294002, respectively). However, these inhibitors did not change the decrease of ROS accumulation as a result of short preincubation with $100 \mu \mathrm{M} \alpha$-T, apparently due to its scavenging effect [23].

\section{5. $\alpha$-T Increases the Basal Level of pAkt and pERK1/2 in Brain Cortical Neurons, but Does Not Change Total Akt and ERK1/2 Levels}

The effect of $\alpha$-T on basal Akt activity (pAkt level) and Akt level in cortical neurons was studied (Figure 3).
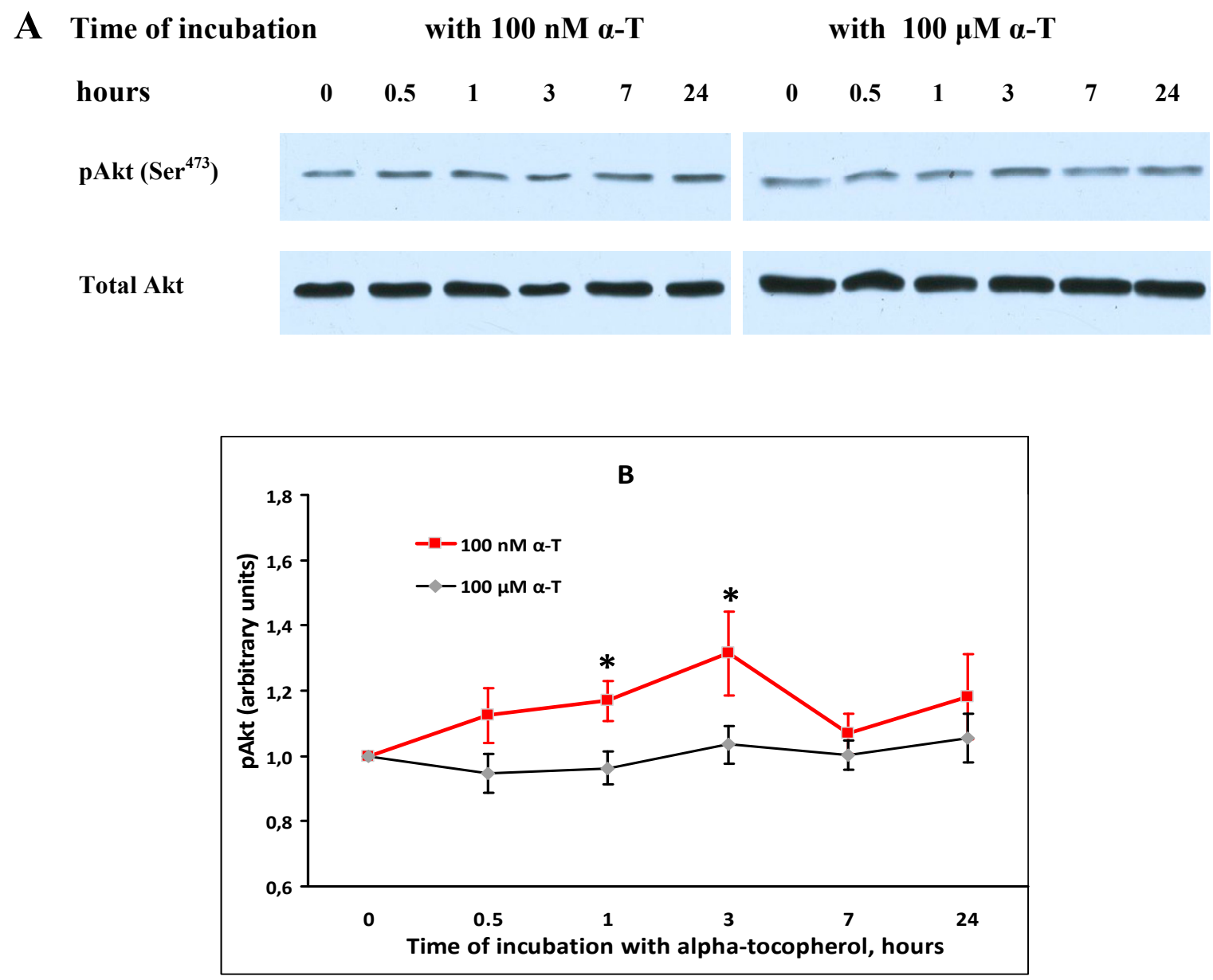

Figure 3. Shows the effect of incubation with $100 \mathrm{nM}$ and $100 \mu \mathrm{M} \alpha$-tocopherol $(\alpha-\mathrm{T})$ for $0.5,1,3,7$ and $24 \mathrm{~h}$ on the level of pAkt and total Akt in brain cortical neurons. Immunoblots obtained in one typical experiment from 6-7 experiments made are presented in (A). The data of 6-7 experiments made are presented as means \pm SEM in (B). Red lines with squares show the effect of $100 \mathrm{nM} \alpha$-T, black lines with rhombs the effect of $100 \mu \mathrm{M} \alpha$-T. In this figure: * - the difference from the control level of pAkt is significant by paired Student's $t$ test after incubation with $100 \mathrm{nM} \alpha-\mathrm{T}, p<0.05$.

$\alpha$-T (100 nM) was found to activate Akt (to increase pAkt level) in control brain cortical neurons 1 and $3 \mathrm{~h}$ after exposure of the cells to this antioxidant (Figure 3A). No change in pAkt level in these neurons was revealed as a result of their incubation with $100 \mu \mathrm{M} \alpha$-T (Figure 3A). No change in total 
Akt level were evidenced after exposure of cortical neurons to $100 \mathrm{nM}$ or $100 \mu \mathrm{M} \alpha$-T, hence it had no influence on the expression of this protein kinase.

The effect of $\alpha$-T on basal ERK1/2 activity (pERK1/2 level) and total ERK1/2 level in brain cortical neurons was studied (Figure 4).

A
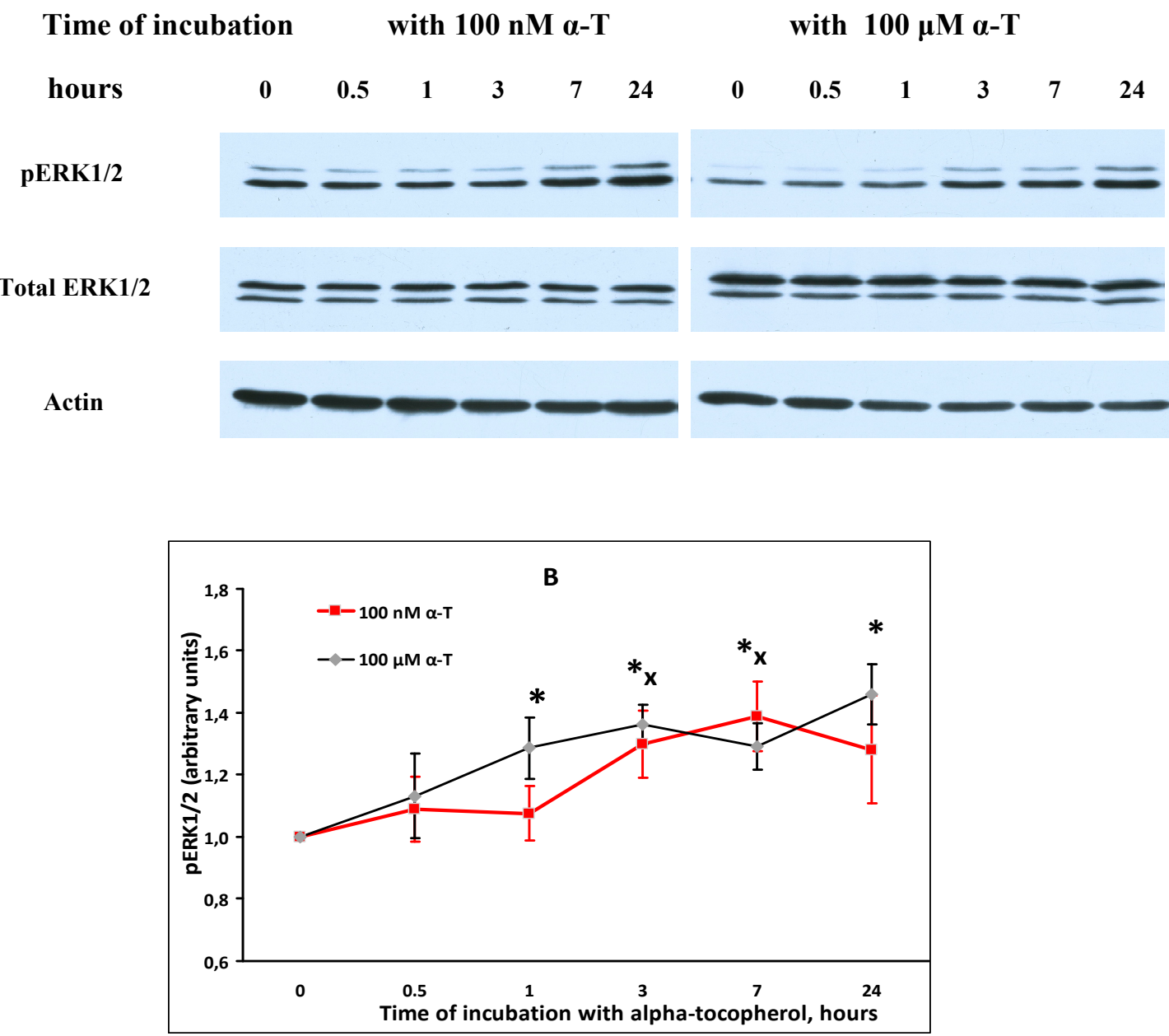

Figure 4. Shows that incubation of brain cortical neurons with $100 \mathrm{nM}$ and $100 \mu \mathrm{M} \alpha$-tocopherol $(\alpha-\mathrm{T})$ increased the level of pERK1/2 in these neurons. Immunoblots obtained in one typical experiment are presented in (A). The data are means \pm SEM from 5-6 experiments in (B). Red lines with squares show the effect of $100 \mathrm{nM} \alpha$-T, black lines with rhombs - the effect of $100 \mu \mathrm{M} \alpha$-T. In this figure the difference is significant by paired Student's $t$-test: *-between pERK1/2 level after exposure to $100 \mu \mathrm{M} \alpha$-T and control pERK1/2 level, $p<0.05$, $\mathbf{x}$-between pERK1/2 level after exposure to $100 \mathrm{nM} \alpha$-T and control pERK1/2 level, $p<0.05$. The level of pERK1/2 significantly increased in brain cortical neurons after their exposure to $100 \mu \mathrm{M} \alpha$-T for 1, 3, 7 and $24 \mathrm{~h}$ and to $100 \mathrm{nM} \alpha-\mathrm{T}$ for 3 and $7 \mathrm{~h}$. However, neither $100 \mathrm{nM}$, nor $100 \mu \mathrm{M} \alpha$-T changed the total ERK1/2 level in brain cortical neurons, so it had no influence on the expression of this protein kinase.

Numakawa and co-authors were the first to show that $\alpha$-T (as well as $\gamma$-tocopherol) at nanomolar concentrations increases the basal activity of Akt and ERK1/2 in brain cortical neurons [10]. Our data are in agreement with their findings, but neither in this work nor in other publications the effect of $\alpha$-T on activities of these protein kinases in neurons or cells of neuronal cell lines was studied under the conditions of oxidative stress. 
2.6. While $\alpha$-T Prevents Akt Inactivation Initiated by $\mathrm{H}_{2} \mathrm{O}_{2}$ in Brain Cortical Neurons, the Effect of $100 \mathrm{nM}$ and $100 \mu M \alpha-T$ Is Similar

The data presented in Figure 5 provide evidence that $\alpha$-T prevents Akt inactivation initiated by $\mathrm{H}_{2} \mathrm{O}_{2}$ in cortical neurons.

A

$$
\mathrm{H}_{2} \mathbf{O}_{2}
$$

$\mathrm{H}_{2} \mathrm{O}_{2}+100$ nM $\alpha-\mathrm{T}$

$\mathrm{H}_{2} \mathrm{O}_{2}+100 \mu \mathrm{M} \alpha-\mathrm{T}$

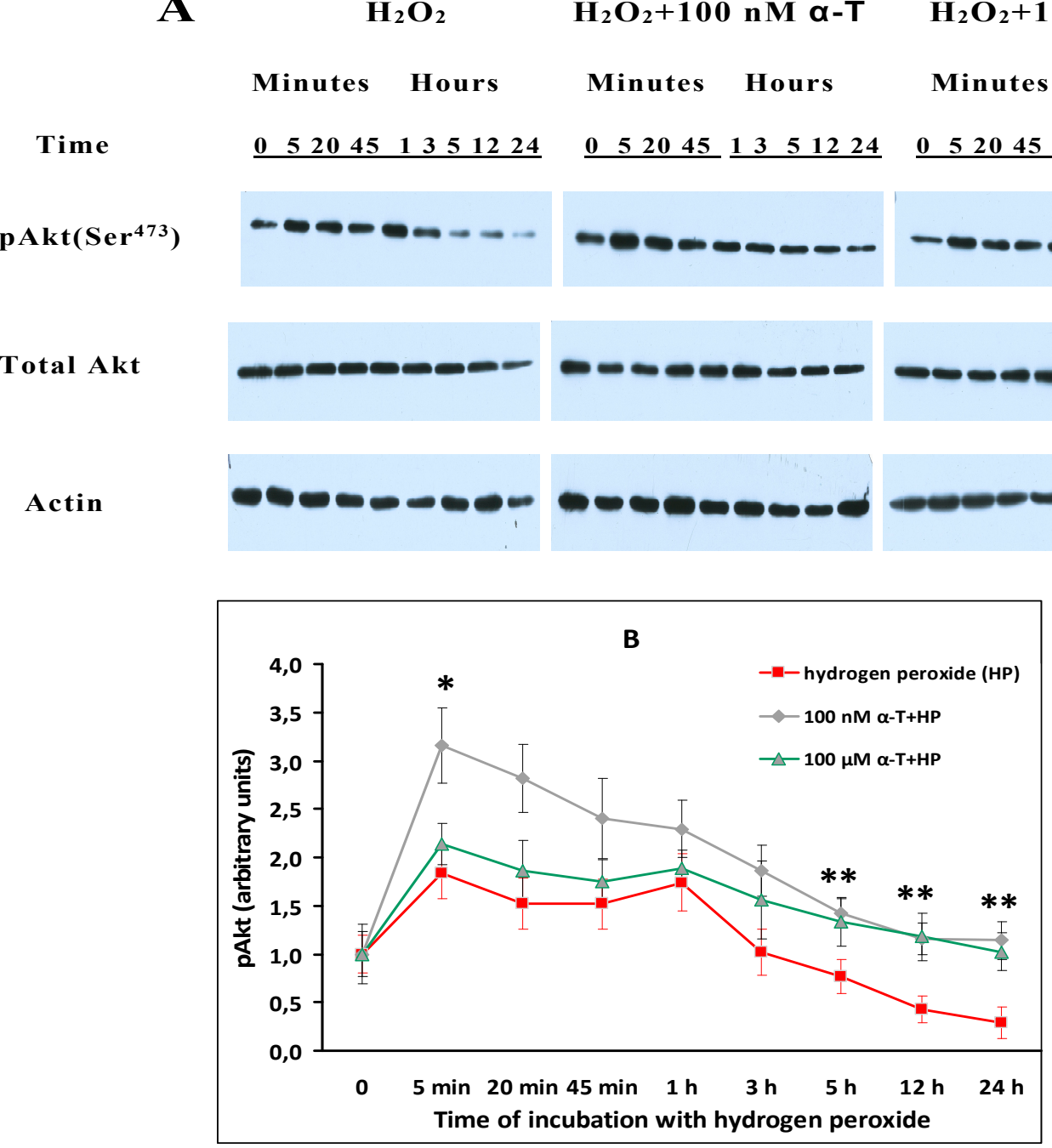

Figure 5. Shows the effect of preincubation of brain cortical neurons with $100 \mathrm{nM}$ and $100 \mu \mathrm{M}$ $\alpha$-tocopherol $(\alpha-\mathrm{T})$ for $18 \mathrm{~h}$ prior to their exposure to $0.2 \mathrm{mM} \mathrm{H}_{2} \mathrm{O}_{2}$ for $24 \mathrm{~h}$ on pAkt and total Akt levels. Immunoblots obtained in one typical experiment are presented in (A). The results of 5-6 experiments are presented in (B) as means \pm SEM. Red lines with squares show the effect of $\mathrm{H}_{2} \mathrm{O}_{2}$ alone, black lines with rhombs-effect of $\mathrm{H}_{2} \mathrm{O}_{2}$ after preincubation with $100 \mathrm{nM} \alpha$-T, green lines with triangles-effect of $\mathrm{H}_{2} \mathrm{O}_{2}$ after preincubation with $100 \mu \mathrm{M} \alpha$-T. In this figure: * and ** -the differences are significant according to Student's paired $t$ test as compared to the level of pERK1/2 in brain cortical neurons exposed to $\mathrm{H}_{2} \mathrm{O}_{2}$ alone; * - the effect of preincubation with $100 \mathrm{nM} \alpha$-T is significant, $p<0.05$; ** the effect of preincubation with both $100 \mathrm{nM}$ and $100 \mu \mathrm{M} \alpha$-T is significant, $p<0.05$.

The data obtained provide evidence that exposure of brain cortical neurons to $0.2 \mathrm{mM} \mathrm{H}_{2} \mathrm{O}_{2}$ results in inactivation of Akt. Thus, the activity of this protein kinase (measured as pAkt level) fell more than twice with respect to control values $12 \mathrm{~h}$ after the application of $\mathrm{H}_{2} \mathrm{O}_{2}$ and more than three times $24 \mathrm{~h}$ after the application of this prooxidant (Figure 5), the difference with the control level being significant $(p<0.01)$. Preincubation with $100 \mathrm{nM}$ and $100 \mu \mathrm{M} \alpha$-T markedly and significantly increased 
Akt activity in cortical neurons (Figure 5) 12 and $24 \mathrm{~h}$ after their exposure to prooxidant with respect to the effect of $\mathrm{H}_{2} \mathrm{O}_{2}$ alone. During the early stages (first $5 \mathrm{~min}$ ), of exposure of cortical neurons to $\mathrm{H}_{2} \mathrm{O}_{2}$ $100 \mathrm{nM} \alpha$-T increased the pAkt level as compared to the effect of $\mathrm{H}_{2} \mathrm{O}_{2}$ alone, whereas $100 \mu \mathrm{M} \alpha$-T did not. Both $\mathrm{H}_{2} \mathrm{O}_{2}$ and $\alpha$-T had no effect on the total Akt level (Figure $5 \mathrm{~A}$ ), which means that they did not change the expression of this enzyme. It is of interest that in contrast to brain cortical neurons, exposure of PC12 cells to $0.2 \mathrm{mM} \mathrm{H}_{2} \mathrm{O}_{2}$ for $24 \mathrm{~h}$ did not result in a pronounced inactivation of Akt [14].

The abrupt drop of Akt activity (Figure 5) revealed in our experiments as a result of cell exposure to $\mathrm{H}_{2} \mathrm{O}_{2}$ appears to be one of the reasons for neuron death. $\alpha$-T prevents the inactivation of Akt under conditions of oxidative stress, but in presence of the PI 3-kinase/Akt signaling pathway inhibitor (LY294002) the protective effect of $\alpha$-T was not observed (see Table 2). These data suggest that the ability of $\alpha$-T to prevent inactivation of Akt in cortical neurons plays an important role in its protective effect against $\mathrm{H}_{2} \mathrm{O}_{2}$ toxicity.

It should be noted that activation of Akt by neurotrophins, flavonoids or other compounds usually leads to an increase of cells (including neurons) viability [24,25]. Conversely, inactivation of Akt results in cell damage and death (see, for example, [26]).

The activation of Akt may occur only after its binding to membrane phosphatidyl-inositol-3, 4, 5-phosphate formed by activated PI 3-kinase. The activation of PI 3-kinase takes place after a stimulus triggered by $\mathrm{G}$ protein coupled receptor or receptor tyrosine kinase. $\mathrm{H}_{2} \mathrm{O}_{2}$ was shown to activate Trk receptor tyrosine kinase [27]. The transient phosphorylation of Akt by $\mathrm{H}_{2} \mathrm{O}_{2}$ takes place downstream of activation of this protein kinase. Thus, the inhibitor of Trk tyrosine kinase (K252a) was shown to diminish Akt activity in PC12 cells exposed to $\mathrm{H}_{2} \mathrm{O}_{2}$ practically to the control level [14]. $\alpha$-T activates Akt in the nerve cells [10,14], but has no effect on the activity of Trk tyrosine kinase. It is possible that $\alpha$-T like glutaredoxin [28] changes the redox state of Akt preventing its oxidation and formation of disulfide bond between two cystein residues of these enzyme elicited by $\mathrm{H}_{2} \mathrm{O}_{2}$. Such changes of Akt structure induced by $\mathrm{H}_{2} \mathrm{O}_{2}$ facilitate association of Akt with protein phosphatase $2 \mathrm{~A}$, its dephosphorylation and subsequent degradation [28], but the presence of antioxidants like glutaredoxin [28] or $\alpha$-T may prevent the effect of prooxidant. In our study, ROS formation in brain cortical neurons exposed to $\mathrm{H}_{2} \mathrm{O}_{2}$ was markedly diminished both by $100 \mu \mathrm{M}$, and by $100 \mathrm{nM} \alpha$-T. Quite possible that it is a result of inhibition of one of the enzymes producing ROS by $\alpha-\mathrm{T}$ [7].

2.7. While $\alpha$-T Decreases the Time of Long Activation of ERK1/2 in Brain Cortical Neurons Initiated by $\mathrm{H}_{2} \mathrm{O}_{2}$, the Effect of $100 \mathrm{nM}$ and $100 \mu \mathrm{M} \alpha$-T Is Similar

The data presented in Figure 6 provide evidence that $\alpha$-T decreases the time of maximal activation of ERK1/2 initiated by $\mathrm{H}_{2} \mathrm{O}_{2}$ in brain cortical neurons.

The maximal level of pERK1/2 was reached within 5 min after neuron exposure to $\mathrm{H}_{2} \mathrm{O}_{2}$ and was then maintained for the whole $24 \mathrm{~h}$ observation period (Figure 6A,B). Preincubation with nanomolar and micromolar $\alpha$-T prevented long and sustained activation of ERK1/2 initiated by $\mathrm{H}_{2} \mathrm{O}_{2}$ in brain cortical neurons. pERK1/2 levels were much lower in neurons preincubated with $100 \mathrm{nM}$ and $100 \mu \mathrm{M}$ $\alpha-\mathrm{T} 5,12$ and $24 \mathrm{~h}$ after beginning to expose the cells to $\mathrm{H}_{2} \mathrm{O}_{2}(p<0.05)$. In cells exposed both to $\alpha-\mathrm{T}$ and $\mathrm{H}_{2} \mathrm{O}_{2}$, a peak instead of a plateau is seen in the histograms (Figure 6B). Neither $\mathrm{H}_{2} \mathrm{O}_{2}$ nor $\alpha-\mathrm{T}$ altered the expression of ERK1/2.

The prolonged activation of ERK1/2 by $\mathrm{H}_{2} \mathrm{O}_{2}$ in brain cortical neurons observed in our study is in agreement with previous data showing the activation of this enzyme by ROS $[29,30] . \alpha$-T decreased the time of maximal activation of ERK1/2 in PC12 cells as well [14], but the maximal activation of ERK1/2 by $\mathrm{H}_{2} \mathrm{O}_{2}$ in these cells lasted for a much shorter time than in cortical neurons. It should be noted that carnosine has a similar effect on ERK1/2 activity; carnosine was shown to protect cerebellar granule cells against oxidative stress and to decrease the time of ERK1/2 activation by a prooxidant [31]. $\alpha$-T similar effect may be the result of a protein phosphatase activation, especially of $2 \mathrm{~A}$. The mechanism of protein phosphatase activation by $\alpha$-T appears to be complicated, as it needs a long preincubation with 
it $[7,8,32]$. Both $\alpha$-T and its derivative which does not have radical scavenging activity were shown to be able to inhibit ERK1/2 activity [33].

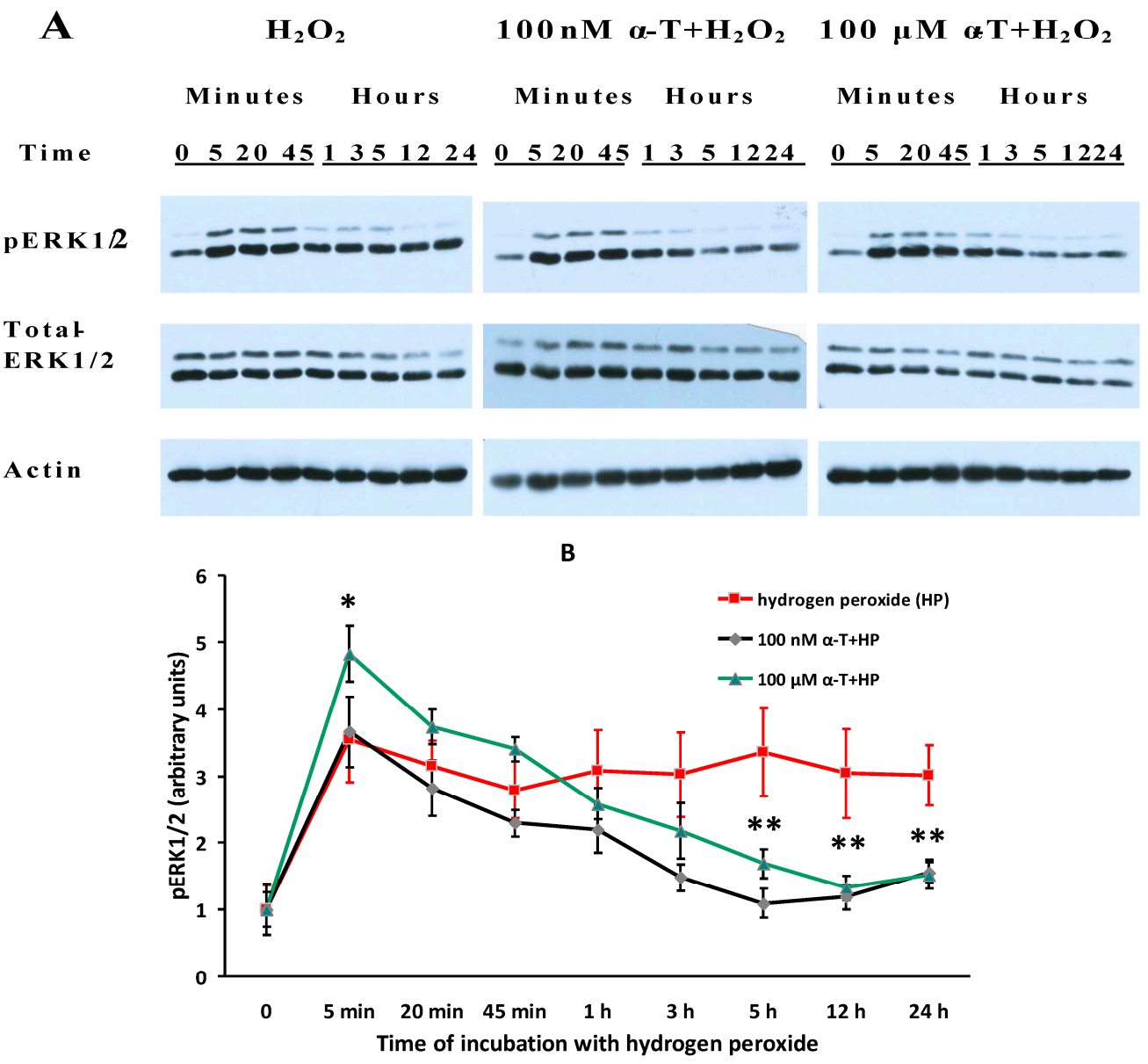

Figure 6. Shows the effect of preincubation of brain cortical neurons with $100 \mathrm{nM}$ and $100 \mu \mathrm{M}$ $\alpha$-tocopherol $(\alpha-\mathrm{T})$ for $18 \mathrm{~h}$ prior to the cell exposure to $0.2 \mathrm{mM} \mathrm{H}_{2} \mathrm{O}_{2}$ for $24 \mathrm{~h}$ on $\mathrm{pERK} 1 / 2$ and total ERK1/2 levels. The immunoblots obtained in one typical experiment are presented in (A). The results of 5-6 experiments are presented in (B) as means \pm SEM. Red lines with squares show the effect of $\mathrm{H}_{2} \mathrm{O}_{2}$ alone, black lines with rhombs-effect of $\mathrm{H}_{2} \mathrm{O}_{2}$ after preincubation with $100 \mathrm{nM} \alpha$ - $\mathrm{T}$, green lines with triangles-effect of $\mathrm{H}_{2} \mathrm{O}_{2}$ after preincubation with $100 \mu \mathrm{M} \alpha$-T. It is shown that $0.2 \mathrm{mM} \mathrm{H}_{2} \mathrm{O}_{2}$ activated ERK1/2 in brain cortical neurons (increased pERK1/2 level) $5 \mathrm{~min}$ after its application, then ERK1/2 remained at the same high level during $24 \mathrm{~h}$ of prooxidant action. However, if these neurons were preincubated with $100 \mathrm{nM}$ and $100 \mu \mathrm{M} \alpha$-T for $18 \mathrm{~h}$ and then exposed to $0.2 \mathrm{mM} \mathrm{H}_{2} \mathrm{O}_{2}$ for $24 \mathrm{~h}$, the activity of ERK1/2 was not high, it was close to control values 12 and $24 \mathrm{~h}$ after exposure of the neurons to this prooxidant, the effect of preincubation with $100 \mathrm{nM}$ and $100 \mu \mathrm{M} \alpha$-T was significant. Preincubation with $\alpha-\mathrm{T}(100 \mu \mathrm{M})$ caused a significant increase of the pERK1/2 level as compared to the effect of $\mathrm{H}_{2} \mathrm{O}_{2}$ alone at early stages of its action $-5 \mathrm{~min}$ after cell exposure to $\mathrm{H}_{2} \mathrm{O}_{2}$, but $100 \mathrm{nM} \alpha$-T did not exert such an effect. No change in the total ERK1/2 level was revealed as a result of the exposure of neurons to $\mathrm{H}_{2} \mathrm{O}_{2}$ alone or to $\mathrm{H}_{2} \mathrm{O}_{2}$ after preincubation with $\alpha-\mathrm{T}$, which means that the expression of this protein kinase was not changed. In this figure: * and ${ }^{* *}$ - the differences are significant according to Student's paired $t$ test as compared to the level of pERK1/2 in brain cortical neurons exposed to $\mathrm{H}_{2} \mathrm{O}_{2}$ alone; *-the effect of preincubation with $100 \mu \mathrm{M} \alpha$-T is significant; $p<0.05$, **-the effect of preincubation with both $100 \mathrm{nM}$ and $100 \mu \mathrm{M} \alpha$-T is significant, $p<0.05$.

It is of interest to note that a short activation of ERK1/2 by neurotrophins, flavonoids or other compounds increases the viability of nerve cells [24,25], whereas long sustained activation of ERK1/2, 
in contrast, leads to nerve cell death. Thus, the exposure of cortical neurons to toxic zinc concentrations was shown to result in a sustained and excessive activation of Ras/MEK1/2/ERK1/2 pathway, mitochondrial dysfunction and neuronal death [34,35]. Glutathione depletion of cortical neurons and cells of HT22 neuroblastoma cell line leads to oxidative stress, sustained activation of ERK1/2 and, ultimately, the death of these cells [36]. When the effect of glutamate on the HT22 neuronal cell line was studied it was found that early activation of ERK1/2 increases cell viability, while conversely, a late activation leads to their death [36]. In vivo oxidative stress caused by ischemic damage is accompanied by sustained activation of ERK1/2 in the brain [37-39]. The administration of inhibitors of MEK1/2/ERK1/2 pathway (including SL327 used in our experiments) to animals subjected to brain ischemia and reperfusion (accompanied by activation of free radical reactions) leads to a pronounced decrease of neuronal death in damaged brain regions and to a marked improvement of the animal functional state [37-39].

In our study, $100 \mathrm{nM}$ and $100 \mu \mathrm{M} \alpha$-T was able to activate ERK1/2 in control cells and at the early stages of the $\mathrm{H}_{2} \mathrm{O}_{2}$ action, and to inhibit this protein kinase at the late stages of the $\mathrm{H}_{2} \mathrm{O}_{2}$ action. The ability of $100 \mathrm{nM}$ and $100 \mu \mathrm{M} \alpha-\mathrm{T}$ to inhibit the ERK1/2 activity at the late stages of prooxidant action was shown to be similar. In the presence of theMEK1/2 inhibitor (SL327), which prevents ERK1/2 activation, the rescue rates of $\alpha$-T were to a great extent and significantly diminished (Table 2). The data obtained suggest that the ability of $\alpha-\mathrm{T}$ at nanomolar and micromolar concentrations to increase the viability of brain cortical neurons depends on its modulation of ERK1/2 activity.

2.8. $\alpha$-T at $100 \mu M$ and $100 n M$ Concentrations Diminishes the Activation of PKC $\delta$ Initiated by $\mathrm{H}_{2} \mathrm{O}_{2}$ in Brain Cortical Neurons

The activation of PKC $\delta$ may happen as a result of its phosphorylation or as a result of its proteolytic cleavage by caspase- 3 . In the latter case, a catalytically active $40-41 \mathrm{kDa}$ fragment is formed as a result of the cleavage of 78-79 kDa PKC $\delta$. Studies made using cells of the PC12 and N27 neuronal cell lines and smooth muscle cells provide evidence that proteolytic cleavage is the main way of PKC $\delta$ activation, leading to the apoptotic death of cells under conditions of oxidative stress initiated by $\mathrm{H}_{2} \mathrm{O}_{2}$ or by 6-hydroxydopamine extracellular auto-oxidation [40-42], whereas necrotic neuronal and muscle cell death is accompanied by increased phosphorylation of $\mathrm{PKC} \delta$, which results in the activation of this protein kinase [41,42]. We used long exposure to a relatively low $\mathrm{H}_{2} \mathrm{O}_{2}$ concentration $\left(0.2 \mathrm{mM} \mathrm{H}_{2} \mathrm{O}_{2}\right.$ for $24 \mathrm{~h}$ ). In our previous work we have shown that, under conditions of oxidative stress initiated by such treatment, the apoptotic death of PC12 cells predominates [14]. That is why we studied the formation of the active $40 \mathrm{kDa}$ fragment in order to assess the PKC $\delta$ activation in brain cortical neurons exposed to $\mathrm{H}_{2} \mathrm{O}_{2}$ (Figure 7).

Our data are in agreement with the data of Ferri and co-authors [43] who have shown that $\alpha-\mathrm{T}$ inhibits PKC $\delta$ activity in the hippocampal dentate gyrus neurons in vivo. PKC $\delta$ activation was shown to increase the death of neurons in a number of studies [44-46]. Thus, it was shown [45] that the dopaminergic neurotoxicant 6-hydroxydopamine (6-OHDA) induced oxidative damage through the proteolytic activation of PKC $\delta$ in mesencephalic dopaminergic neuronal N27 cells. It is of interest that the activation of PKC $\delta$ was completely suppressed by treatment with a caspase-3-specific inhibitor. Expression of caspase-3 cleavage resistant mutant PKC $\delta$ (D327A) and kinase dead PKC $\delta$ (K376R) or siRNA-mediated knockdown of PKC $\delta$ protected against 6-OHDA-induced neuronal cell death [45]. In the works of Zhang and co-authors [44], it has been shown that the PKC $\delta$ isoform is an oxidative stress-sensitive kinase and a key mediator of apoptotic cell death in Parkinson's disease models. Rottlerin was found to decrease PKC $\delta$ activity to a great extent in primary cultures of mesencephalic neurons. The neuroprotective effect of rottlerin was shown in both cell culture and preclinical animal models of Parkinson's disease [44]. 
Time of incubation with $\mathrm{H}_{2} \mathrm{O}_{2}$

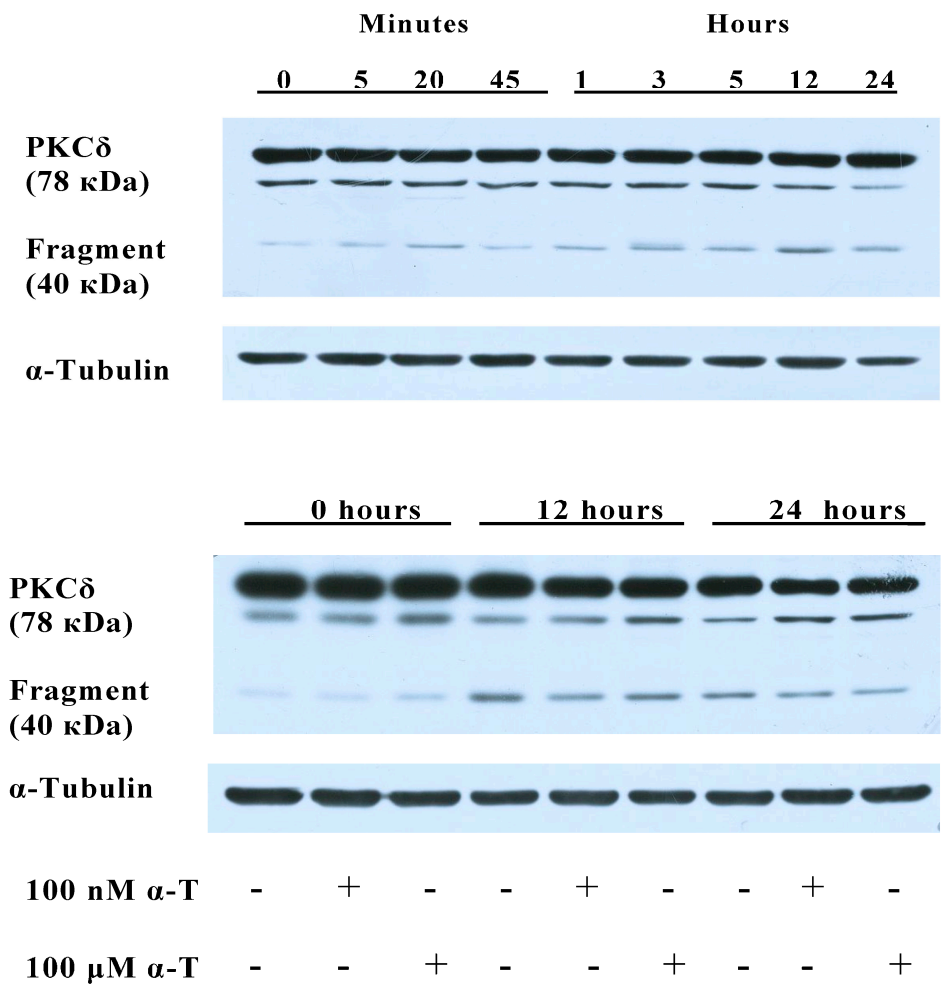

Figure 7. Shows the effect of $\mathrm{H}_{2} \mathrm{O}_{2}$ and preincubation with $\alpha$-tocopherol $(\alpha-\mathrm{T})$ on the level of the active fragment of PKC $\delta$ with molecular mass $40 \mathrm{kDa}$ and the level of total PKC $\delta$ in brain cortical neurons. These neurons were preincubated with $100 \mathrm{nM}$ and $100 \mu \mathrm{M} \alpha$-T (or without it) for $18 \mathrm{~h}$ and then exposed to $0.2 \mathrm{mM} \mathrm{H}_{2} \mathrm{O}_{2}$ for $24 \mathrm{~h}$. Immunoblots obtained in one typical experiment (from 5 experiments made) show that $\mathrm{H}_{2} \mathrm{O}_{2}$ increased the level of catalytically active $40 \mathrm{kDa}$ fragment of PKC $\delta$ in neurons up to $12 \mathrm{~h}$ after the beginning of their exposure to this prooxidant. It means that $\mathrm{H}_{2} \mathrm{O}_{2}$ activated PKC $\delta$ in brain cortical neurons. However, preincubation with $100 \mathrm{nM}$ and $100 \mu \mathrm{M} \alpha$-T diminished the increase of the level of $40 \mathrm{kDa}$ fragment of PKC $\delta$ induced by $\mathrm{H}_{2} \mathrm{O}_{2} \cdot \mathrm{H}_{2} \mathrm{O}_{2}$ and $\alpha$-T had no effect on total PKC $\delta$ level (Figure 7), which means that they did not change the expression of this enzyme.

The generation of PKC $\delta$ catalytic fragment in cell nuclei by caspase- 3 cleavage of PKC $\delta$ is a critical step leading to apoptotic cell death initiated by many apoptotic stimuli [47-49]. This $40-41 \mathrm{kDa}$ fragment of PKC $\delta$ forms complexes with DNA protein kinases, phosphorylates and inactivates them, leads to chromatin condensation and nuclear fragmentation, to phosphorylation and activation of p73-beta (structural and functional homologue of the p53 tumor suppressor), to redistribution and activation of proapoptotic protein Bax that can directly induce cytochrome $\mathrm{c}$ release from the mitochondria, activates such enzymes as scramblases, responsible for phosphatidylserine translocation to outer leaflet of lipid bilayer, that leads to the apoptotic cell elimination [48-50]. It is of interest that the PKC $\delta$ catalytic fragment is not only a product of caspase- 3 action on $\mathrm{PKC} \delta$, but is able to activate caspase- 3 itself, enhancing the level of apoptosis $[47,48]$. Thus, PKC $\delta$ catalytic fragment has targets in various compartments of the cells, its numerous metabolic effects lead to cell apoptosis and death. In the present work we showed that neuron exposure to $\mathrm{H}_{2} \mathrm{O}_{2}$ results in the formation of catalytically active $40 \mathrm{kDa}$ fragment of PKC $\delta$. At the same time, preincubation of brain cortical neurons with $100 \mathrm{nM}$ or $100 \mu \mathrm{M} \alpha$-T markedly diminishes such activation. In the presence of the PKC $\delta$ inhibitor rottlerin, the protective effect of $\alpha$-T against $\mathrm{H}_{2} \mathrm{O}_{2}$-induced death of cortical neurons was significantly lower than in its absence (see Table 2). All the above-mentioned data suggest that modulation of PKC $\delta$ activity by $\alpha$-T makes a pronounced contribution to its protective effect against the toxic action of $\mathrm{H}_{2} \mathrm{O}_{2}$ on brain cortical neurons. 
It should be noted that $\alpha$-T inhibits the activity not only of PKC $\delta$, but of other forms of this protein kinase as well, as has been shown in numerous studies. Thus, for example, the supplementation of pregnant rats with high doses of vitamin $\mathrm{E}$ or $\alpha$-T was found to potentiate $\alpha$-T incorporation in the hippocampus of their offsprings and to lead to a marked decrease of brain PKC phosphorylation throughout their postnatal maturation. Offsprings of $\alpha$-T supplemented pregnant rats showed a pronounced reduction of long-term synaptic plasticity. The impairment of brain function was observed even in adulthood, thus, in adult rats a deficit in long-lasting spatial memory, which depends on the function of hippocampus, was shown [51]. The data obtained indicate [52] that gestational and neonatal exposure to supranutritional $\alpha$-T intake can result in anatomical changes of the offspring hippocampus (in particular in an aberrant glia-synapse relationship) that last through adulthood.

In order to understand the physiological meaning of the results on the modulation of protein kinase activities by $\mathrm{H}_{2} \mathrm{O}_{2}$ and $\alpha$-T in cultured neurons it is of importance to know if these results may be applied to brain in pathological conditions. The toxic effects of sustained ERK1/2 activation [37-39], of PKC $\delta$ activation by caspase-3 cleavage [44], of Akt oxidation and inactivation [28] are revealed in brain under pathological conditions concerned with activation of ROS formation. It gives additional interest to the data on the mechanism of nanomolar and micromolar $\alpha$-T protective action in cultured nerve cells.

We studied the possible contribution of modulation of ERK1/2, Akt and PKC $\delta$ activity to the protective effect of $\alpha$-T against $\mathrm{H}_{2} \mathrm{O}_{2}$-induced death of brain cortical neurons, but it is to be noted that the protective effect of $\alpha$-T may depend also on modulation of other signaling pathways.

2.9. $\alpha$-T at Micro- and Nanomolar Concentrations Prevents the Abrupt Decrease of Bcl-2 Level and the Marked Increase of the Bax/Bcl-2 Ratio Initiated by $\mathrm{H}_{2} \mathrm{O}$ in Brain Cortical Neurons

In order to elucidate the mechanism of the $\alpha$-T protective effect under conditions of oxidative stress it is of importance not only to study its effect on the cell signaling pathways, but to obtain data on its ability to stabilize mitochondria, in particular to modulate the expression, level and activity of the pro- and antiapoptotic mitochondrial proteins. The effect of cortical neuron exposure to $\alpha-T$ on basal Bax/Bcl-2 ratio is shown in Figure 8.

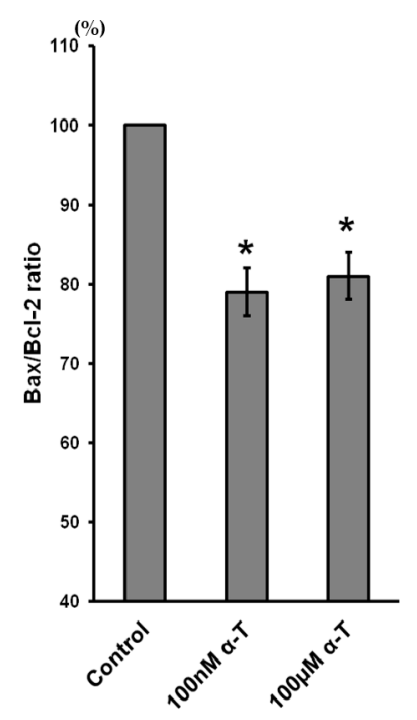

Figure 8. Shows the effect of incubation of brain cortical neurons with $\alpha$-tocopherol $(\alpha-\mathrm{T})$ for $18 \mathrm{~h}$ on the basal Bax/Bcl-2 ratio. This ratio was taken as $100 \%$ in control brain cortical neurons. The data of five experiments made are presented as means \pm SEM. $\alpha$-T (100 nM and $100 \mu \mathrm{M})$ was shown to decrease the basal Bax/Bcl-2 ratio in brain cortical neurons. The diminution of this ratio was not pronounced, but it was significant. *-the difference is significant according to Student's paired $t$ test as compared to the $\mathrm{Bax} / \mathrm{Bcl}-2$ ratio in control cortical neurons, $p<0.02$. 
But more important for us was to see the effect of nanomolar and micromolar $\alpha$-T on the level of Bax and Bcl-2 under conditions of oxidative stress induced by $\mathrm{H}_{2} \mathrm{O}_{2}$ in brain cortical neurons. The experimental data obtained are presented in Figure 9.

A

$$
\mathbf{H}_{2} \mathbf{O}_{2}
$$

$100 \mathrm{nM} \alpha-\mathrm{T}+\mathrm{H}_{2} \mathrm{O}_{2}$

$100 \mu \mathrm{M} \alpha-\mathbf{T}+\mathrm{H}_{2} \mathrm{O}_{2}$

\section{Minutes Hours Minutes Hours Minutes Hours}

Time $\begin{array}{llllllllllllllllllllllllllll}0 & 5 & 20 & 45 & 1 & 3 & 5 & 12 & 24 & 0 & 5 & 20 & 45 & 1 & 3 & 5 & 12 & 24 & 0 & 5 & 20 & 45 & 1 & 3 & 5 & 12 & 24\end{array}$

Bcl-2

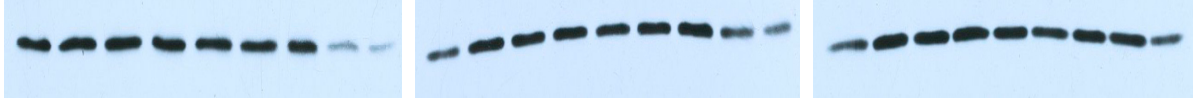

Bax

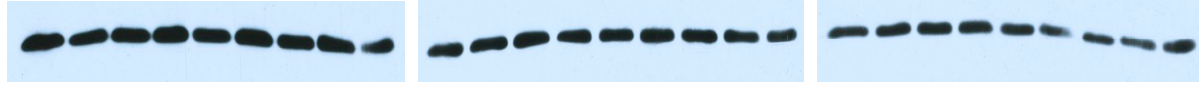

Actin

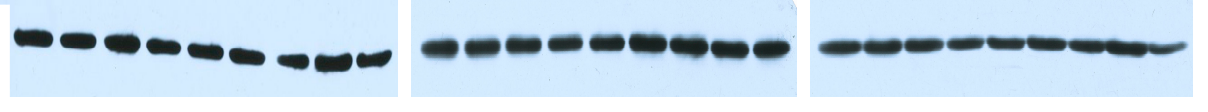

B
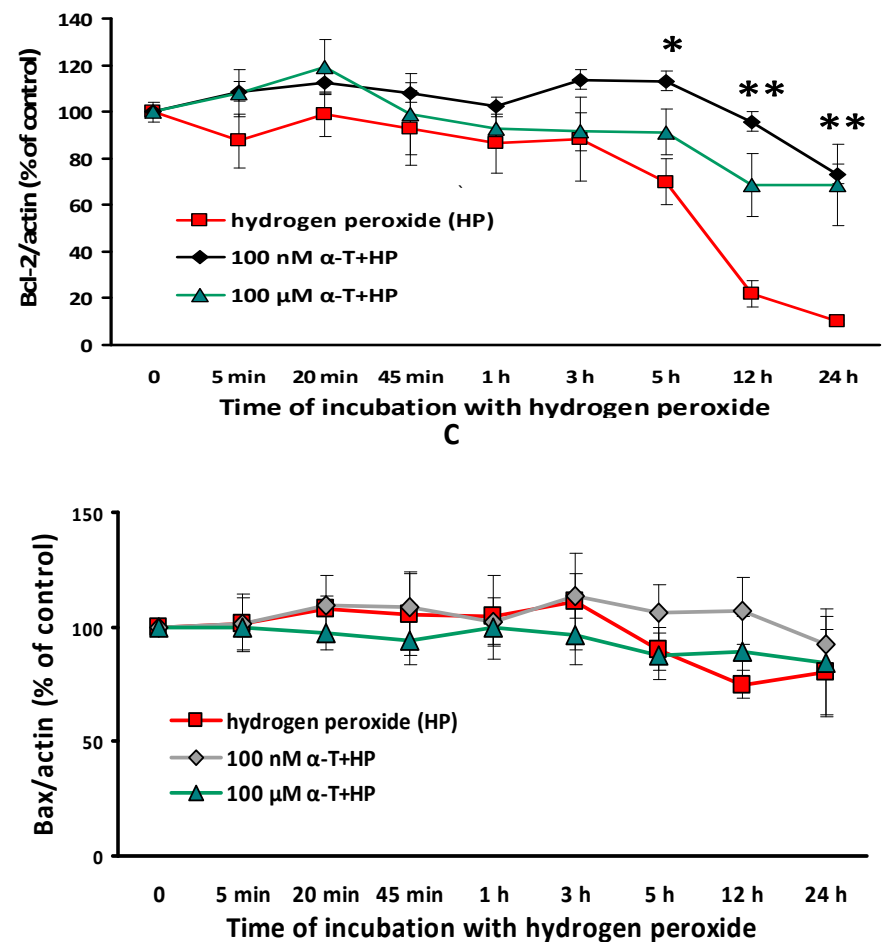

Figure 9. Shows the effect of exposure of cortical neurons to $0.2 \mathrm{mM} \mathrm{H}_{2} \mathrm{O}_{2}$ for $24 \mathrm{~h}$ and of preincubation with $100 \mathrm{nM}$ and $100 \mu \mathrm{M} \alpha$-tocopherol $(\alpha-\mathrm{T})$ for $18 \mathrm{~h}$ on the level of Bcl-2 and Bax in brain cortical neurons. The results of immunoblotting obtained in one typical experiment are shown in (A). The results of 6-7 experiments are shown in $(\mathbf{B}, \mathbf{C})$, respectively, as means \pm SEM. Red lines with squares show the effect of $\mathrm{H}_{2} \mathrm{O}_{2}$ alone, black lines with rhombs-effect of $\mathrm{H}_{2} \mathrm{O}_{2}$ after preincubation with $100 \mathrm{nM} \alpha$-T, green lines with triangles-effect of $\mathrm{H}_{2} \mathrm{O}_{2}$ after preincubation with $100 \mu \mathrm{M} \alpha$-T. * and ** - the differences are significant according to Student's paired $t$ test as compared to the level of Bcl-2 in brain cortical neurons exposed to $\mathrm{H}_{2} \mathrm{O}_{2}$ alone, * the effect of preincubation with $100 \mathrm{nM} \alpha-\mathrm{T}$ is significant, ${ }^{*} p<0.05,{ }^{* *}$ the effect of preincubation with both $100 \mathrm{nM}$ and $100 \mu \mathrm{M} \alpha-\mathrm{T}$ is significant, $p<0.02$. 
It was found that $\mathrm{H}_{2} \mathrm{O}_{2}$ had practically no effect on the content of the antiapoptotic protein Bcl-2 in brain cortical neurons for the first $3 \mathrm{~h}$ after the application of $\mathrm{H}_{2} \mathrm{O}_{2}$. The small decrease in Bcl-2 level $5 \mathrm{~h}$ after exposure of the cells to $\mathrm{H}_{2} \mathrm{O}_{2}$ was found to be significant $(p<0.05)$. Then, an abrupt decrease in the level of this antiapoptotic protein started (Figure 9B). Thus, the Bcl-2 level 12 and $24 \mathrm{~h}$ after exposure of cortical neurons to $\mathrm{H}_{2} \mathrm{O}_{2}$ was much lower with respect to its initial level (0 point), this diminution being highly significant $(p<0.001)$. However if brain cortical neurons were preincubated with $100 \mathrm{nM}$ or $100 \mu \mathrm{M} \alpha$-T and then exposed to $\mathrm{H}_{2} \mathrm{O}_{2}$ the decrease in Bcl-2 content practically did not happen 12 and $24 \mathrm{~h}$ after cell exposure to this prooxidant. At these time intervals of exposure of the cells to $\mathrm{H}_{2} \mathrm{O}_{2}$, preincubation with $100 \mathrm{nM}$ or $100 \mu \mathrm{M} \alpha$-T significantly increased the Bcl-2 level in cortical neurons compared to the effect of $\mathrm{H}_{2} \mathrm{O}_{2}$ alone (Figure 9B).

The proapoptotic protein Bax did not show such a pronounced alteration of its level after brain cortical neuron exposure to $\mathrm{H}_{2} \mathrm{O}_{2}$ as Bcl-2. Preincubation with $100 \mathrm{nM}$ or $100 \mu \mathrm{M} \alpha$-T did not have any significant effect on Bax level (Figure 9C).

The data showing the effect of $\mathrm{H}_{2} \mathrm{O}_{2}$ and $\alpha$-T on Bax/Bcl-2 ratio in brain cortical neurons are presented in Figure 10.

A pronounced and significant increase of the Bax/Bcl-2 ratio 12 and $24 \mathrm{~h}$ after exposure of cortical neurons to $\mathrm{H}_{2} \mathrm{O}_{2}$ alone appears to be mainly a result of the abrupt decrease of Bcl-2 level under conditions of oxidative stress. However, preincubation with nanomolar or micromolar $\alpha$-T resulted in a pronounced increase of Bcl-2 level 12 and $24 \mathrm{~h}$ after brain neuron exposure to the prooxidant, as clearly seen in the immunoblots (Figure 10A). Our data showing that preincubation of neurons with $\alpha$-T decreases Bax/Bcl-2 ratio (or increases "survival index"-Bcl-2/Bax ratio) in the neurons are in agreement with the data of Then and co-authors [53].

The long effect of $0.2 \mathrm{mM} \mathrm{H}_{2} \mathrm{O}_{2}$ on neurons or neuronal cell lines usually leads mainly to apoptotic cell death; thus it was shown in our study of the effect of $\mathrm{H}_{2} \mathrm{O}_{2}$ on PC12 cells [14], but necrotic death of a certain part of brain cortical neurons exposed to $\mathrm{H}_{2} \mathrm{O}_{2}$ cannot be excluded.

Proapoptotic mitochondrial proteins play an important role in the apoptotic death of various cells including neurons, while the increase of expression and level of antiapoptotic proteins, in contrast, decreases the apoptotic death rate (see, for example [54,55]). It is of interest that such proapoptotic proteins as Bax and Bak were at first considered to have no effect on the necrotic cell death, until data were obtained on their interaction with adenine nucleotide translocase which plays an important role in the permeability of the mitochondrial inner membrane and in mPTP function [56-58]. It was shown that Bax and Bak deletion decreases necrotic damage and death of cells in knockout mice with myocardial infarction [58], while the excessive expression of the antiapoptotic protein Bcl-2 may lead to the diminution of necrotic cell death [59]. It appears that mitochondrial pro- and antiapoptotic proteins like Bax, Bak, Bcl-2 and others determine both apoptotic and necrotic cell death.

In the literature there are data showing that the expression, level and activity of mitochondrial anti- and proapoptotic proteins may depend on the activity of Akt, ERK1/2 [25,60] and PKC [56,61]. The effect of activation of various forms of PKC may be opposite [61]. According to our data presented above the inactivation of Akt and the maintenance of maximal ERK1/2 activity are induced by $\mathrm{H}_{2} \mathrm{O}_{2}$ at approximately the same time or somewhat earlier than the great decrease of Bcl-2 level and the increase of Bax/Bcl-2 ratio in brain cortical neurons. At the same time, preincubation with $\alpha$-T prevents both the alterations in the activity of ERK1/2 and Akt, and the decrease of the Bcl-2 level and increase of the $\mathrm{Bax} / \mathrm{Bcl}-2$ ratio in brain cortical neurons. It may be suggested that the normalization of Akt, ERK1/2 and PKC $\delta$ activity by $\alpha$-T in brain cortical neurons exposed to $\mathrm{H}_{2} \mathrm{O}_{2}$ makes a great contribution to normalization of the Bax/Bcl-2 ratio in these cells. It is of interest that all these metabolic effects of $\alpha-\mathrm{T}$ were very similar if it was used at micromolar or nanomolar concentrations. 
A Time of incubation with $\mathrm{H}_{2} \mathrm{O}_{2}$
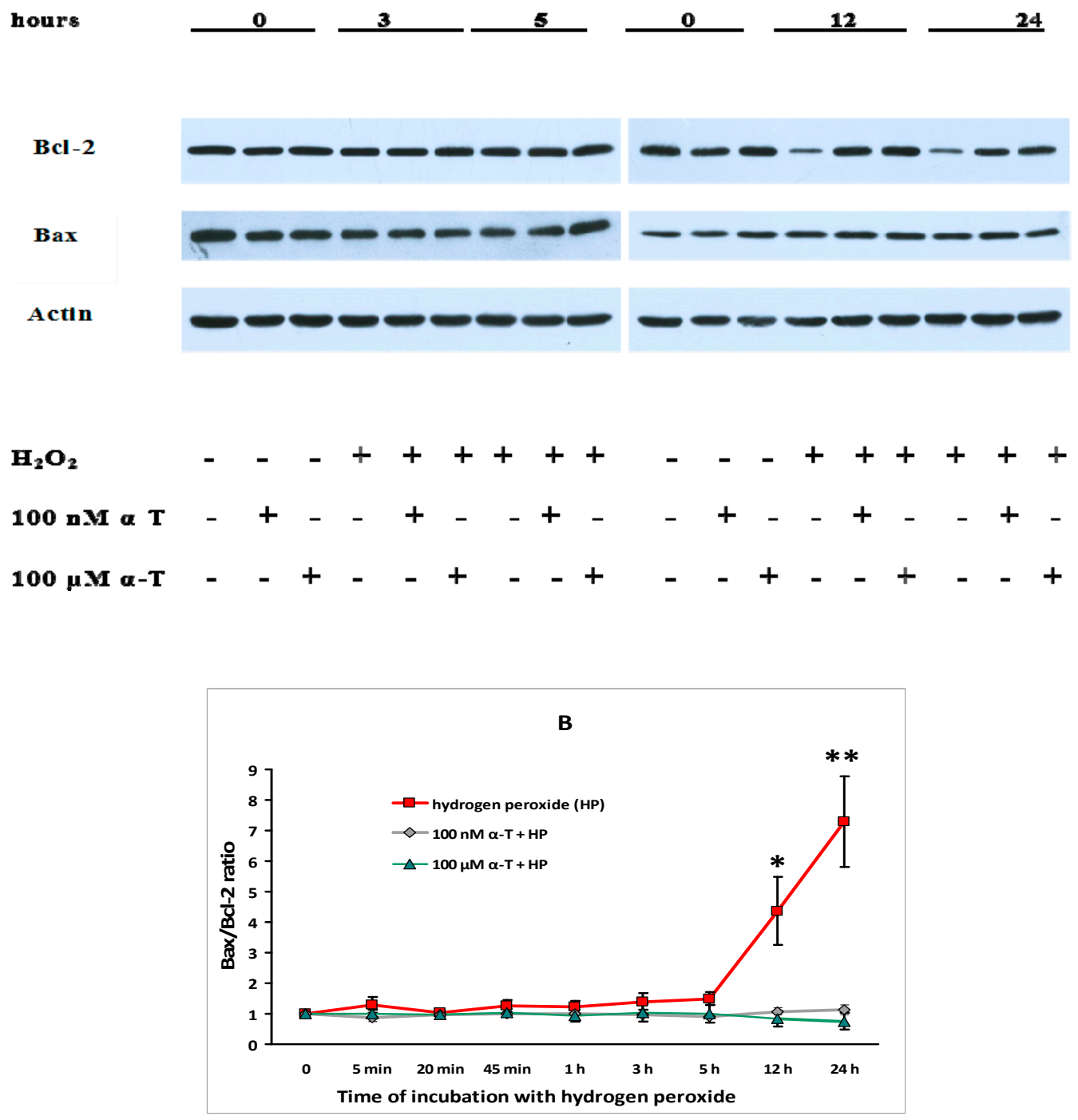

Figure 10. Shows the effect of $\mathrm{H}_{2} \mathrm{O}_{2}$ and preincubation with $\alpha$-tocopherol $(\alpha-\mathrm{T})$ on the Bax/Bcl-2 ratio in brain cortical neurons. The levels of Bcl-2 and Bax 3, 5, 12 and $24 \mathrm{~h}$ after brain cortical neuron exposure to $0.2 \mathrm{mM} \mathrm{H}_{2} \mathrm{O}_{2}$ after preincubation for $18 \mathrm{~h}$ with $100 \mathrm{nM} \alpha-\mathrm{T}$ and $100 \mu \mathrm{M} \alpha-\mathrm{T}$ (or without it) are shown in (A). The results of five experiments on the Bax/Bcl-2 ratio in brain cortical neurons are presented as means $\pm S E M$ in (B). Red lines with squares show the effect of $\mathrm{H}_{2} \mathrm{O}_{2}$ alone, black lines with rhombs-effect of $\mathrm{H}_{2} \mathrm{O}_{2}$ after preincubation with $100 \mathrm{nM} \alpha$-T, green lines with triangles-effect of $\mathrm{H}_{2} \mathrm{O}_{2}$ after preincubation with $100 \mu \mathrm{M} \alpha$-T. ${ }^{*}$ and ${ }^{*}$ - the differences are significant according to Student's paired $t$ test as compared to the initial level of Bax/Bcl-2 ratio (0 point) and to the level of this ratio in brain cortical neurons exposed to $\mathrm{H}_{2} \mathrm{O}_{2}$ after preincubation with $100 \mathrm{nM}$ and $100 \mu \mathrm{M} \alpha-\mathrm{T}$, ${ }^{*} p<0.05,{ }^{* *} p<0.02$. It means that the effect of preincubation with both $100 \mathrm{nM}$ and $100 \mu \mathrm{M} \alpha-\mathrm{T}$ is significant.

\section{Materials and Methods}

\subsection{Materials}

$\alpha-\mathrm{T}, \mathrm{H}_{2} \mathrm{O}_{2}, \mathrm{NADH}$, cytosine arabinoside were purchased in Sigma (Saint-Louis, MO, USA), K-252a, SL327, LY284002 and rottlerin were obtained from Calbiochem (San Diego, CA, USA), penicillin and streptomycin came from Serva (Heidelberg, Germany). The incubation media, Dulbecco's 
modified Eagle Medium (DMEM) with L-glutamine, fetal calf blood serum were from Biolot Company (Saint-Petersburg, Russia). In the Immunoblotting section the information about various antibodies which were needed for experiments is given.

\subsection{Brain Cortical Neurons in Culture}

Brains of embryonic Wistar rat fetuses (day 17-18) were used to isolate cortical neurons and prepare primary cultures of cortical neurons by modified method of Dichter [62] as previously described [63]. Wistar rats were obtained from the Animal Facilities of I.M. Sechenov Institute of Evolutionary Physiology and Biochemistry of the Russian Academy of Sciences (IEPhB RAS, Saint-Petersburg, Russia). All procedures using animals were in accordance with the European Communities Council Directive of 24 November 1986, 86/609/EEC and were approved by the local Animal Care and Use Committee of IEPhB RAS. DMEM containing 10\% fetal calf serum, 10\% F12 medium, $2 \mathrm{mM}$ glutamine and $20 \mathrm{mM}$ Hepes was used as the complete incubation medium. Cells were seeded on poly-D-lysine coated 24-well plates at a density of $5 \times 10^{5}$ cells per well. After $24 \mathrm{~h}$, cytosine-arabinoside $(1 \mu \mathrm{M})$ was added to culture for $24 \mathrm{~h}$ in order to minimize growth of glial cells. Culture medium was replaced every 3 days. Treatments were performed on the 5-th day in vitro. Preincubation of neurons with $\alpha$-T was performed for 0.5 or $18 \mathrm{~h}$ in complete incubation medium prior to the exposure of cells to $0.2 \mathrm{mM} \mathrm{H}_{2} \mathrm{O}_{2}$ for $24 \mathrm{~h}$ in complete incubation medium. In some experiments neurons were preincubated in the presence of protein kinase inhibitors (SL327, LY294002 or rottlerin) for $0.5 \mathrm{~h}$ in complete incubation medium before the exposure of the cells to $\alpha$-T.

\subsection{Assessment of Cell Viability Using the Lactate Dehydrogenase (LDH) Method}

LDH method was used to determine viability of immature brain cortical neurons. This method is based on evaluation of activity of LDH released to the incubation medium from the damaged cells. Before the aliquots were taken from the incubation medium the centrifugation of the samples was performed. In order to determine the activity of LDH in the samples the decrease of NADH level was measured in them. This reaction took place in the incubation medium containing $80 \mathrm{mM}$ tris- $\mathrm{HCl} \mathrm{pH}$ 7.2, $1.6 \mathrm{mM}$ pyruvate, $0.2 \mathrm{mM}$ NADH and $200 \mathrm{mM} \mathrm{NaCl}$. In order to measure the decrease of NADH level the decrease of optical density of the samples was registered at $340 \mathrm{~nm}$ during approximately 5-6 min as previously described [64], M40 spectrophotometer (Karl-Zeisse, Germany) was used for this purpose. The total LDH activity of the samples was determined after the lysis of the neurons. It was performed in presence of $1 \%$ Triton X-100 at room temperature. The percent of LDH activity released to the incubation medium from the damaged cells to the total LDH activity in the sample was determined. If $100 \%$ of $\mathrm{LDH}$ activity is found in the incubation medium it means that all cells are dead.

In order to show the protective effect of $\alpha$-T in various series of experiments its rescue rates were calculated. For this purpose the difference in the amount (activity) of LDH released from cortical neurons exposed to $\mathrm{H}_{2} \mathrm{O}_{2}$ in the absence and in the presence of of $\alpha$-T was determined. Then the ratio of this difference to the increase of $\mathrm{LDH}$ amount released from neurons to the incubation medium in the presence of $\mathrm{H}_{2} \mathrm{O}_{2}$ alone (taken for $100 \%$ ) was calculated. Such value corresponds to rescue rate of $\alpha$-T against $\mathrm{H}_{2} \mathrm{O}_{2}$-induced neuron death. Thus, the rescue rate may be calculated in the following way: ([LDH release in $\mathrm{H}_{2} \mathrm{O}_{2}-\mathrm{LDH}$ release in $\mathrm{H}_{2} \mathrm{O}_{2}$ and $\left.\alpha-\mathrm{T}\right] /$ [LDH release in $\mathrm{H}_{2} \mathrm{O}_{2}-\mathrm{LDH}$ release in control] $) \times 100$.

\subsection{Determination of ROS Accumulation}

Incubation with $\alpha$-T was carried out as described in previous sections. The fluorescent dye dichlorodihydrofluorescein diacetate was added to the incubation medium to a final concentration of $25 \mu \mathrm{M}$. After $40 \mathrm{~min}$ incubation, the cells were exposed to $0.3 \mathrm{mM} \mathrm{H}_{2} \mathrm{O}_{2}$ for $4 \mathrm{~h}$ [65]. In order to remove dye excess the cells were washed with Hanks' balanced salt solution. The fluorescence of the reaction product of ROS with dichlorodihydrofluorescein was determined using a Fluoroscan Ascent FL (Thermo Fisher Scientific, Vantaa, Finland) measuring the emission at $\lambda=523 \mathrm{~nm}$ after excitation at 
$485 \mathrm{~nm}$. The ROS content was expressed in arbitrary units representing the intensity of the fluorescence of the reaction product.

\subsection{Immunoblotting}

Western-blot analysis was used to determine the expression and activity of ERK1/2, Akt and, expression of Bcl-2, Bax and PKC $\delta$. Brain cortical neurons were exposed to $\alpha-\mathrm{T}, \mathrm{H}_{2} \mathrm{O}_{2}$ and other compounds like inhibitors (if needed), then they were washed twice using ice-cold PBS and scrapped in lysis buffer, which consisted of $50 \mathrm{mM}$ Tris $\mathrm{pH}$ 8.0, $150 \mathrm{mM} \mathrm{NaCl}, 1 \%$ Triton X-100, $10 \mathrm{mM}$ $\beta$-glycerophosphate $\mathrm{Na}, 10 \mathrm{mM} \mathrm{NaF}, 5 \mathrm{mM}$ EDTA, $1 \mathrm{mM} \mathrm{Na}_{3} \mathrm{VO}_{4}, 1 \mathrm{mM}$ phenyl methyl sulfonyl fluoride (PMSF), and protease inhibitor cocktail (Roche, Mannheim, Germany). Complete lysis of cortical neurons was performed during $1 \mathrm{~h}$ on ice. To determine protein concentration in cell lysates the Lowry method with Folin and Ciocaltteu's Phenol reagent was used, the protein determinations were performed in duplicate and bovine serum albumin was used as a standard. Protein-containing lysates were put in each lane in the equivalent amount $(20-25 \mu \mathrm{g})$. Electrophoresis was performed in $10 \%$ sodium dodecyl sulfate-polyacrilamide gel. It was followed by transfer to pure nitrocellulose membranes (Schleicher \& Schuell, Krackeler Scientific, Albany, NY, USA). The non-specific binding sites of the membranes were blocked with $20 \mathrm{mM}$ Tris- $\mathrm{HCl}$ buffer ( $\mathrm{pH} 7,6)$ containing $150 \mathrm{mM} \mathrm{NaCl}$ (TBS), $5 \%(w / v)$ skimmed milk and $0.1 \%$ Tween 20 . The blots were then probed overnight with antibodies for pERK1 (pThr ${ }^{202} /$ pTyr $\left.^{204}\right)$ and pERK2 (pThr ${ }^{185} /$ pTyr $\left.^{187}\right)$ (1:2000, Sigma), pAkt (Ser $\left.{ }^{473}\right)$ (1:1000, Cell Signaling, Danvers, MA, USA), Bcl-2 (1:1000, Cell Signaling), Bax (1:1000, Cell Signaling) or PKC $\delta$ (C-17) (1:1000, Santa Cruz Biotechnology, Dallas, TX, USA). Then they were washes three times using $0.1 \%$ Tween 20 in TBS. Anti-mouse or anti-rabbit HRP-labeled secondary antibodies (Cell Signaling) were used. After the incubation with them for $1 \mathrm{~h}$ at the room temperature blots were developed, using for this purpose Enhanced chemiluminescence detection Wester blotting reagents (Amersham, GE Healthcare, Little Chalfont, UK). The data were normalized then. For this purpose membranes were incubated in the buffer, containing $65 \mathrm{mM}$ Tris, pH 6.8, 2\% SDS (w/v), and $\beta$-mercaptoethanol in order to strip antibodies previously used and re-probe with the antibodies for actin (1:100, Sigma), $\alpha$-tubulin (1:2000), Akt (pan) (Cell Signaling) or total ERK1/2 (Cell Signaling). The quantification of optical densities of the positive bands of the scanned films was performed using NIH Image Analysis software version 1.43 (Bethesda, MD, USA).

\subsection{Statistical Analysis}

Data are presented as the means \pm SEM. The significance of the differences between two groups of data was assessed by Student's $t$-test and Student's paired $t$-test. The statistical significance of differences between three or more groups of data was estimated using one-way analysis of variance (ANOVA) followed by Tukey's post hoc multiple comparison test. Values of $p<0.05$ were taken to be statistically significant.

\section{Conclusions}

Our work is one of the first attempts to study the mechanism of protective effect of $\alpha-\mathrm{T}$ at nanomolar concentrations, which are its physiological concentrations in cerebrospinal fluid and brain extracellular space. The protective effect of $\alpha$-T against the $\mathrm{H}_{2} \mathrm{O}_{2}$ toxic effect on the brain cortical neurons was found to be concentration-dependent in the nanomolar range $(1<10<100 \mathrm{nM})$ if the preincubation with it was performed for $18 \mathrm{~h}$. The maximal protection could be achieved by the preincubation for $18 \mathrm{~h}$ with $100 \mathrm{nM} \alpha$-T in serum containing medium (complete incubation medium); a further increase of $\alpha$-T concentration $(1,10$ and $100 \mu \mathrm{M})$ did not result in a significant increase of the protective effect, but nanomolar $\alpha$-T did not protect cortical neurons if preincubation was made for $0.5 \mathrm{~h}$.

The possible contribution of modulation of ERK1/2, Akt and PKC $\delta$ activity by $\alpha$-T to its protective effect against $\mathrm{H}_{2} \mathrm{O}_{2}$ toxicity was studied. Preincubation for $18 \mathrm{~h}$ with $\alpha$-T at nanomolar and micromolar 
concentrations was found to prevent the inactivation of Akt and sustained activation of ERK1/2 maintained at a high level from $5 \mathrm{~min}$ to $24 \mathrm{~h}$ after exposure of the neurons to $\mathrm{H}_{2} \mathrm{O}_{2}$. Long preincubation with $\alpha$-T diminished the activation of PKC $\delta$ elicited in cortical neurons by $\mathrm{H}_{2} \mathrm{O}_{2}$ alone. In the presence of inhibitors of MEK1/2/ERK1/2 or PI 3-kinase/Akt signaling pathways or of PKC $\delta$ the protective effect of $\alpha$-T at nanomolar and micromolar concentrations was significantly diminished or disappeared. One of the ways by which modulation of activities of protein kinases ERK1/2, Akt and PKC may change the viability of neurons and other cells is their effect on the content of proapoptotic and antiapoptotic mitochondrial proteins. $\mathrm{H}_{2} \mathrm{O}_{2}$ was shown to cause an abrupt decrease of the level of $\mathrm{Bcl}-2$ protein and a pronounced increase of the proapoptotic to antiapoptotic protein ratio (Bax/Bcl-2 ratio) in brain cortical neurons 12 and $24 \mathrm{~h}$ after the exposure of the cells to it, while after preincubation of neurons with $\alpha$-T at nanomolar and micromolar concentrations Bcl-2 level was much higher and Bax/Bcl-2 ratio was much lower (close to control values) than in the case of neuron exposure to $\mathrm{H}_{2} \mathrm{O}_{2}$ alone.

$\alpha$-T at concentrations of $100 \mathrm{nM}$ and $100 \mu \mathrm{M}$ was found to have an approximately similar metabolic effects on brain cortical neurons if preincubation with it was performed for $18 \mathrm{~h}$. Thus, the ability of $100 \mathrm{nM}$ and $100 \mu \mathrm{M} \alpha-\mathrm{T}$ to modulate Akt, ERK1/2 and PKC $\delta$ activity and to prevent the changes of the Bax/Bcl-2 ratio under conditions of oxidative stress was found to be very similar. However, micromolar $\alpha$-T diminished ROS formation induced by $\mathrm{H}_{2} \mathrm{O}_{2}$ to a higher extent than nanomolar $\alpha$-T, but much shorter time of neuron exposure to $\mathrm{H}_{2} \mathrm{O}_{2}(4 \mathrm{~h})$ was used in these experiments than in the case of determination of $\alpha$-T effect on the viability of neurons $(24 \mathrm{~h})$.

It appears that the similar protective effect of nanomolar and micromolar $\alpha$-T cannot be explained by the fact that nanomolar $\alpha$-T may accumulate in neurons in the course of long preincubation. Thus, according to the data obtained by Saito and co-authors [13] the presence of $100 \mathrm{nM} \alpha-\mathrm{T}$ in the incubation medium does not lead to any increase in the $\alpha$-T content of brain cortical neurons after $24 \mathrm{~h}$ of incubation with this antioxidant, but the presence of $1 \mu \mathrm{M} \alpha-\mathrm{T}$ in the incubation medium for $24 \mathrm{~h}$ leads to accumulation of approximately $250 \mathrm{pmol}$ of $\alpha$-T per mg of protein in brain cortical neurons. That is in contrast to $\alpha$-tocotrienol which penetrates better to the cortical neurons and accumulates in them even if it is present in the incubation medium in nanomolar concentrations (100-250 nM) [13].

Taking into account the data on the similar protection of brain cortical neurons exposed to $\mathrm{H}_{2} \mathrm{O}_{2}$ by nanomolar and micromolar $\alpha$-T obtained in the present study, a "more is better" approach to patients' supplementation with vitamin $\mathrm{E}$ or $\alpha$-T appears not to be reasonable. There are examples of unfavorable effects or possible unfavorable effects of vitamin $\mathrm{E}$ or $\alpha$-T administration in high doses to humans and animals. They provide evidence that the mechanism of the protective action of $\alpha$-T is quite complicated and not limited to scavenging activity only. As it was already mentioned, vitamin E administration in high doses was found to increase significantly the all-cause mortality in adult patients as well as for people in risk groups [1-3]. The possible mechanism of negative outcomes of supplementation of brain by $\alpha-T$ at high doses was shown in mice with acute ischemic brain stroke [4]. A poststroke increase in markers of oxidative injury and neurodegeneration and activation of microglia were shown to take place in the presence of elevated brain $\alpha$-T. At supraphysiological level, $\alpha$-T potentiated neuroinflammatory responces to active ischemic stroke [4]. Another example is a recommendation for an increased intake of the antioxidant $\alpha$-T (vitamin E) by women in complicated pregnancies in order to prevent free radical damage to mother and fetus [52]. However, recent data showed that maternal vitamin $\mathrm{E}(\alpha-\mathrm{T})$ supplementation to rats potentiated $\alpha$-T incorporation in the brain (including hippocampus) of offsprings and led to a marked decrease of PKC phosphorylation, marked reduction of long-term synaptic plasticity in juvenile hippocampus and even to a deficit in long-lasting spatial memory in adulthood of offspring [51,52]. Such results raise concerns about the potential effects of increased $\alpha-\mathrm{T}$ (vitamin E) intake by pregnant women on fetal brain development. All these data suggest that it is of importance to perform further studies of mechanism of $\alpha$-T action on neurons and other brain cells at its physiological nanomolar concentrations present in brain extracellular space making its comparison with the mechanism of $\alpha$-T action at much higher micromolar concentrations. 
$\alpha$-T belongs to the protectors that modulate signaling pathways and decrease the intensity of free radical reactions in neurons and other cells, like flavonoids, $N$-acetyl-L-carnosine, gangliosides and insulin. If the mechanism of the protective action of these natural compounds is better understood, there is a chance to reveal the combinations in which they additively or synergistically increase the protective effect of each other. Finally, the common use of some of these compounds may appear effective in preclinical and clinical trials as a remedy in neurodegenerative and brain ischemic diseases. It seems that such an approach might have an advantage compared to attempts to reveal the protective effect of $\alpha$-T or vitamin E administration over a long time and in appreciable amounts to patients with various diseases and people in risk groups.

Acknowledgments: The work was supported by grants from the Russian Fund for Basic Research No. 13-04-00643 and No. 16-04-00408.

Author Contributions: Irina O. Zakharova, conceived and designated the experiments, performed the experiments using immunoblotting technique, Tatiana V. Sokolova conceived and designated the experiments, performed the experiments on isolation and cultivation of brain cortical neurons and on determination of neuron viability, Yulia A. Vlasova performed the experiments on the reactive oxygen species production by neurons, Liubov V. Bayunova performed the experiments using immunoblotting technique, Maria P. Rychkova performed the experiments on the determination of neuron viability, Natalia F. Avrova wrote the manuscript, conceived and designated the experiments, all the authors analyzed the data obtained, read and approved the final text of the manuscript.

Conflicts of Interest: The authors declare no conflict of interest.

\section{Abbreviations}

$\begin{array}{ll}\alpha \text {-T } & \alpha \text {-tocopherol } \\ \text { ERK1/2 } & \text { extracellular signal-regulated protein kinase } \\ \text { PI 3-kinase } & \text { phosphatidylinositol 3-kinase } \\ \text { Akt } & \text { protein kinase B } \\ \text { PKC } & \text { protein kinase C } \\ \text { ROS } & \text { reactive oxygen species }\end{array}$

\section{References}

1. Miller, E.R.; Pastor-Barriuso, R.; Dalal, D.; Riemersma, R.; Appel, L.J.; Guallar, E. Meta-analysis: High-dosage vitamin E supplementation may increase all-cause mortality. Ann. Intern. Med. 2005, 142, 37-46. [CrossRef] [PubMed]

2. Bjelakovic, G.; Nikolova, D.; Gluud, L.L.; Simonetti, R.G.; Gluud, C. Mortality in randomized trials of antioxidant supplements for primary and secondary prevention. Systematic review and meta-analysis. J. Am. Med. Assoc. 2007, 297, 842-857. [CrossRef] [PubMed]

3. Bjelakovic, G.; Nikolova, D.; Gluud, C. Meta-regression analyses, meta-analyses, and trial sequential analyses of the effects of supplementation with beta-carotene, vitamin A, and vitamin E singly or in different combinations on all-cause mortality: Do we have evidence for lack of harm? PLoS ONE 2013, 8, e74558. [CrossRef] [PubMed]

4. Khanna, S.; Heigel, M.; Weist, J.; Gnyawali, S.; Teplitsky, S.; Roy, S.; Sen, C.K.; Rink, C. Excessive $\alpha$-tocopherol exacerbates microglial activation and brain injury caused by acute ischemic stroke. FASEB J. 2015, 29, 828-836. [CrossRef] [PubMed]

5. Vatassery, G.T.; Adityanjee; Quach, H.T.; Smith, W.E.; Kuskowski, M.A.; Melnyk, D. $\alpha$ and $\gamma$ tocopherols in cerebrospinal fluid and serum from older, male, human subjects. J. Am. Coll. Nutr. 2004, 23, 233-238. [CrossRef] [PubMed]

6. De Bustos, F.; Jimenez-Jimenez, F.J.; Molina, J.A.; Esteban, J.; Guerrero-Sola, A.; Zurdo, M.; Orti-Pareja, M.; Tallon-Barranco, A.; Gomez-Escalonilla, C.; Ramirez-Ramos, C.; et al. Cerebrospinal fluid levels of $\alpha$-tocopherol in amyotrophic lateral sclerosis. J. Neural Transm. 1998, 105, 703-708. [CrossRef] [PubMed]

7. Zingg, J.M. Modulation of signal transduction by vitamin E. Mol. Aspects Med. 2007, 28, 481-506. [CrossRef] [PubMed] 
8. Azzi, A. Molecular mechanism of $\alpha$-tocopherol action. Free Radic. Biol. Med. 2007, 43, 16-21. [CrossRef] [PubMed]

9. Galli, F.; Azzi, A. Present trends in vitamin E research. Biofactors 2010, 36, 33-42. [CrossRef] [PubMed]

10. Numakawa, Y.; Numakawa, T.; Matsumoto, T.; Yagasaki, Y.; Kumamaru, E.; Kunugi, H.; Taguchi, T.; Niki, E. Vitamin E protected cultured cortical neurons from oxidative stress-induced cell death through the activation of mitogen-activated protein kinase and phosphatidylinositol 3-kinase. J. Neurochem. 2006, 97, 1191-1202. [CrossRef] [PubMed]

11. Khanna, S.; Roy, S.; Ryu, H.; Bahaddun, P.; Swaan, P.W.; Ratian, R.R.; Sen, C.K. Molecular basis of vitamin E action: Tocotrienol modulates 12-lipoxygenase, a key mediator of glutamate-induced neurodegeneration. J. Biol. Chem. 2003, 278, 43508-43515. [CrossRef] [PubMed]

12. Khanna, S.; Parinandi, N.L.; Kotha, S.R.; Roy, S.; Rink, C.; Bibus, D.; Sen, C.K. Nanomolar vitamin $\mathrm{E} \alpha$-tocotrienol inhibits glutamate-induced activation of phospholipase $\mathrm{A}_{2}$ and causes neuroprotection. J. Neurochem. 2010, 112, 1249-1260. [CrossRef] [PubMed]

13. Saito, Y.; Saito, Y.; Nishio, K.; Akazawa, Y.O.; Yamanaka, K.; Miyama, A.; Yoshida, Y.; Noguchi, N.; Niki, E. Cytoprotective effects of vitamin $\mathrm{E}$ homologues against glutamate-induced cell death in immature primary cortical neuron cultures: Tocopherols and tocotrienols exert similar effects by antioxidant function. Free Radic. Biol. Med. 2010, 49, 1542-1549. [CrossRef] [PubMed]

14. Zakharova, I.O.; Sokolova, T.V.; Bayunova, L.V.; Vlasova, Y.A.; Rychkova, M.P.; Avrova, N.F. $\alpha$-Tocopherol at nanomolar concentration protects PC12 cells from hydrogen peroxide-induced death and modulates protein kinase activities. Int. J. Mol. Sci. 2012, 13, 11543-11568. [CrossRef] [PubMed]

15. Di Donato, I.; Bianchi, S.; Federico, A. Ataxia with vitamin E deficiency: Update of molecular diagnosis. Neurol. Sci. 2010, 31, 511-515. [CrossRef] [PubMed]

16. Ames, D.; Ritchie, C. Antioxidants and Alzheimer's disease: Time to stop feeding vitamin $\mathrm{E}$ to dementia patients? Int. Psychogeriatr. 2007, 19, 1-8. [CrossRef] [PubMed]

17. Cuddihy, S.L.; Ali, S.S.; Musiec, E.S.; Lucero, J.; Kopp, S.J.; Morrow, J.D.; Dugan, L.L. Prolonged $\alpha$-tocopherol deficiency decreases oxidative stress and unmasks $\alpha$-tocopherol-dependent regulation of mitochondrial function in the brain. J. Biol. Chem. 2008, 283, 6915-6924. [CrossRef] [PubMed]

18. De Jesus Ferreira, M.C.; Crouzin, N.; Barbanel, G.; Cohen-Solal, C.; Recasens, M.; Vignes, M.; Guiramand, J. A transient treatment of hippocampal neurons with $\alpha$-tocopherol induces a long-lasting protection against oxidative damage via a genomic action. Free Radic. Biol. Med. 2005, 39, 1009-1020. [CrossRef] [PubMed]

19. Crouzin, N.; Ferreira, M.C.; Cohen-Solal, C.; Barbanel, G.; Guiramand, J.; Vignes, M. Neuroprotection induced by vitamin $\mathrm{E}$ against oxidative stress in hippocampal neurons: Involvement of TRPV1 channels. Mol. Nutr. Food Res. 2010, 54, 496-505. [CrossRef] [PubMed]

20. Kondo, K.; Obitsu, S.; Ohta, S.; Matsunami, K.; Otsuka, H.; Teshima, R. Poly(ADP-ribose) polymerase (PARP)-1-independent apoptosis-inducing factor (AIF) release and cell death are induced by eleostearic acid and blocked by $\alpha$-tocopherol and MEK inhibition. J. Biol. Chem. 2010, 285, 13079-13091. [CrossRef] [PubMed]

21. Susarla, B.T.S.; Robinson, M.B. Rottlerin, an inhibitor of protein kinase C $\delta$ (PKC $\delta$ ), inhibits astrocytic glutamate transport activity and reduces GLAST immunoreactivity by a mechanism that appears to be PKC $\delta$-independent. J. Neurochem. 2003, 86, 635-645. [CrossRef] [PubMed]

22. Wu, S.N.; Wang, Y.J.; Lin, M.W. Potent stimulation of large-conductance $\mathrm{Ca}^{2+}$-actiated $\mathrm{K}^{+}$channels by rottlerin, an inhibitor of protein kinase $\mathrm{C}-\delta$, in pituitary tumor $\left(\mathrm{GH}_{3}\right)$ cells and in cortical neuronal $(\mathrm{HCN}-1 \mathrm{~A})$ cells. J. Cell Physiol. 2007, 210, 655-666. [CrossRef] [PubMed]

23. Vlasova, Y.A.; Avrova, N.F. Antioxidant effects of $\alpha$-tocopherol at nanomolar concentrations: The role of the modulation of the activity of signaling systems. Neurochem. J. 2010, 4, 178-184. [CrossRef]

24. Ziegler, C.G.; Sicard, F.; Sperber, S.; Ehrhart-Bornstein, M.; Bornstein, S.R.; Krug, A.W. DHEA reduces NGF-mediated cell survival in serum-deprived PC12 cells. Ann. N. Y. Acad. Sci. 2006, 1073, 306-311. [CrossRef] [PubMed]

25. Vauzour, D.; Vafeiadou, K.; Rice-Evans, C.; Williams, R.J.; Spencer, J.P. Activation of pro-survival Akt and ERK1/2 signalling pathways underlie the anti-apoptotic effects of flavanones in cortical neurons. J. Neurochem. 2007, 103, 1355-1367. [CrossRef] [PubMed] 
26. Yin, X.; Ren, M.; Jiang, H.; Cui, S.; Wang, S.; Jiang, H.; Qi, Y.; Wang, J.; Wang, X.; Dong, G.; Leeds, P.; Chuang, D.M.; Feng, H. Downregulated AEG-1 together with inhibited PI3K/Akt pathway is associated with reduced viability of motor neurons in an ALS model. Mol. Cell Neurosci. 2015, 68, 303-313. [CrossRef] [PubMed]

27. Zakharova, I.O.; Sokolova, T.V.; Vlasova, Y.A.; Furaev, V.V.; Rychkova, M.P.; Avrova, N.F. GM1 ganglioside activates ERK1/2 and Akt downstream of Trk tyrosine kinase and protects PC12 cells against hydrogen peroxide toxicity. Neurochem. Res. 2014, 39, 2262-2275. [CrossRef] [PubMed]

28. Murata, H.; Ihara, Y.; Nakamura, H.; Yodoi, J.; Sumikawa, K.; Kondo, T. Glutaredoxin exerts an antiapoptotic effect by regulating the redox state of Akt. J. Biol. Chem. 2003, 278, 50226-50233. [CrossRef] [PubMed]

29. Daou, G.B.; Srivastava, A.K. Reactive oxygen species mediate Endothelin-1-induced activation of ERK1/2, $\mathrm{PKB}$, and Pyk2 signaling, as well as protein synthesis, in vascular smooth muscle cells. Free Radic. Biol. Med. 2004, 37, 208-215. [CrossRef] [PubMed]

30. Wu, H.; Ichikawa, S.; Tani, C.; Zhu, B.; Tada, M.; Shimoishi, Y.; Murata, Y.; Nakamura, Y. Docosahexaenoic acid induces ERK1/2 activation and neuritogenesis via intracellular reactive oxygen species production in human neuroblastoma SH-SY5Y cells. Biochim. Biophys. Acta 2009, 1791, 8-16. [CrossRef] [PubMed]

31. Kulebyakin, K.; Karpova, L.; Lakonsteva, E.; Krasavin, M.; Boldyrev, A. Carnosine protects neurons against oxidative stress and modulates the time profile of MAPK cascade signaling. Amino Acids 2012, 43, 91-96. [CrossRef] [PubMed]

32. Azzi, A.; Breyer, I.; Feher, M.; Ricciarelli, R.; Stocker, A.; Zimmer, S.; Zingg, J. Nonantioxidant functions of $\alpha$-tocopherol in smooth muscle cells. J. Nutr. 2001, 131, 378S-381S. [PubMed]

33. Yano, T.; Yajima, S.; Hagiwara, K.; Kumadaki, I.; Yano, Y.; Otani, S.; Uchida, M.; Ichikawa, T. Vitamin E inhibits cell proliferation and the activation of extracellular signal-regulated kinase during the promotion phase of lung tumorigenesis irrespective of antioxidative effect. Carcinogenesis 2000, 21, 2129-2133. [CrossRef] [PubMed]

34. He, K.; Aizenman, E. ERK signaling leads to mitochondrial dysfunction in extracellular zinc-induced neurotoxicity. J. Neurochem. 2010, 114, 452-461. [CrossRef] [PubMed]

35. Ho, Y.; Samarasinghe, R.; Knoch, M.E.; Lewis, M.E.; Aizenman, E.; DeFranco, D.B. Selective inhibition of mitogen-activated protein kinase phosphatases by zinc accounts for extracellar signal-regulated kinase 1/2-dependent oxidative neuronal cell death. Mol. Pharmacol. 2008, 74, 1141-1151. [CrossRef] [PubMed]

36. Luo, Y.; DeFranco, D.B. Opposing roles for ERK $1 / 2$ in neuronal oxidative toxicity: Distinct mechanisms of ERK $1 / 2$ action at early versus late phases of oxidative stress. J. Biol. Chem. 2006, 281, 16436-16442. [CrossRef] [PubMed]

37. Namura, S.; Iihara, K.; Takami, S.; Nagata, I.; Kikuchi, H.; Matsushita, K.; Moskowitz, M.A.; Bonventre, J.V.; Alessandrini, A. Intravenous administration of MEK inhibitor UO126 affords brain protection against forebrain ischemia and focal cerebral ischemia. Proc. Natl. Acad. Sci. USA 2001, 98, 11569-11574. [CrossRef] [PubMed]

38. Wang, X.; Wang, H.; Xu, L.; Rozanski, D.J.; Sugawara, T.; Chan, P.H.; Trzaskos, J.M.; Feuerstein, G.Z. Significant neuroprotection against ischemic brain injury by inhibition of the MEK1 protein kinase in mice: Exploration of potential mechanism associated with apoptosis. J. Pharmacol. Exp. Therap. 2003, 304, 172-178. [CrossRef] [PubMed]

39. Lu, K.; Liang, C.L.; Liliang, P.C.; Yang, S.-H.; Cho, C.L.; Weng, H.C.; Tsai, Y.-D.; Wang, K.W.; Chen, H.J. Inhibition of extracellular signal-regulated kinases $1 / 2$ provides neuroprotection in spinal cord ischemia/reperfusion injury in rats: Relationship with the nuclear factor-kB-regulated anti-apoptotic mechanisms. J. Neurochem. 2010, 114, 237-246. [CrossRef] [PubMed]

40. Hanrott, K.; Gudmunsen, L.; O'Neill, M.J.; Wonnacott, S. 6-Hydroxydopamine-induced apoptosis is mediated via extracellular auto-oxidation and caspase 3-dependent activation of proteinkinase C $\delta$. J. Biol. Chem. 2006, 281, 5373-5382. [CrossRef] [PubMed]

41. Carvour, M.; Song, C.; Kaul, S.; Anantharam, V.; Kanthasamy, A.; Kanthasamy, A. Chronic low-dose oxidative stress induces caspase-3-dependent PKC $\delta$ proteolyticactivation and apoptosis in a cell culture model of dopaminergic neurodegeneration. Ann. N. Y. Acad. Sci. 2008, 1139, 197-205. [CrossRef] [PubMed]

42. Kato, K.; Yamanouchi, D.; Esbona, K.; Kamiya, K.; Zhang, F.; Kent, K.C.; Liu, B. Caspase-mediated protein kinase $\mathrm{C}-\delta$ cleavage is necessary for apoptosis of vascular smooth muscle cells. Am. J. Physiol. Heart Circ. Physiol. 2009, 297, 2253-2261. [CrossRef] [PubMed] 
43. Ferri, P.; Cecchini, T.; Ambrogini, P.; Betti, M.; Cuppini, R.; del Grande, P.; Ciaroni, S. $\alpha$-Tocopherol affects neuronal plasticity in adult rat dentate gyrus: The possible role of PKC $\delta$. J. Neurobiol. 2006, 66, 793-810. [CrossRef] [PubMed]

44. Zhang, D.; Anantharam, V.; Kanthasamy, A.; Kanthasamy, A.G. Neuroprotective effect of protein kinase C $\delta$ inhibitor rottlerin in cell culture and animal models of Parkinson's disease. J. Pharmacol. Exp. Ther. 2007, 322, 913-922. [CrossRef] [PubMed]

45. Latchoumycandane, C.; Anantharam, V.; Jin, H.; Kanthasamy, A.; Kanthasamy, A. Dopaminergic neurotoxicant 6-OHDA induces oxidative damage through proteolytic activation of PKC $\delta$ in cell culture and animal models of Parkinson's disease. Toxicol. Appl. Pharmacol. 2011, 256, 314-323. [CrossRef] [PubMed]

46. Jin, H.; Kanthasamy, A.; Harischandra, D.S.; Kondru, N.; Ghosh, A.; Panicker, N.; Anantharam, V.; Rana, A.; Kanthasamy, A.G. Histone hyperacetylation up-regulates protein kinase $C \delta$ in dopaminergic neurons to induce cell death: Relevance to epigenetic mechanisms of neurodegeneration in Parkinson disease. J. Biol. Chem. 2014, 289, 34743-34767. [CrossRef] [PubMed]

47. Sun, F.; Kanthasamy, A.; Song, C.; Yang, Y.; Anantharam, V.; Kanthasamy, A.G. Proteasome inhibitor-induced apoptosis is mediated by positive feedback amplification of PKC $\delta$ proteolytic activation and mitochondrial translocation. J. Cell. Mol. Med. 2008, 12, 2467-2481. [CrossRef] [PubMed]

48. Basu, A. Involvement of protein kinase C- $\delta$ in DNA-damage induced apoptosis. J. Cell. Mol. Med. 2003, 7, 341-350. [CrossRef] [PubMed]

49. DeVries-Seimon, T.A.; Ohm, A.M.; Humphries, M.J.; Reyland, M.T. Induction of apoptosis is driven by nuclear retention of protein kinas C $\delta$. J. Biol. Chem. 2007, 282, 22307-22314. [CrossRef] [PubMed]

50. Sitailo, L.A.; Tibudan, S.S.; Denning, M.F. Bax activation and induction of apoptosis in human keratinocytes by the protein kinase C- $\delta$ catalytic domain. Investig. Dermatol. 2004, 123, 434-443. [CrossRef] [PubMed]

51. Betti, M.; Ambrogini, P.; Minelli, A.; Floridi, A.; Lattanzi, D.; Ciuffoli, S.; Bucherelli, C.; Prospero, E.; Frontini, A.; Santarelli, L.; et al. Maternal dietary load of $\alpha$-tocopherol depress protein kinase $C$ signaling and synaptic plasticity in rat postnatal developing hippocampus and promotes permanent deficits in adult offspring. J. Nutr. Biochem. 2011, 22, 60-70. [CrossRef] [PubMed]

52. Salucci, S.; Ambrogini, P.; Lattanzi, D.; Betti, M.; Gobbi, P.; Galati, C.; Galli, F.; Cuppini, R.; Minelli, A. Maternal dietary loads of $\alpha$-tocopherol increase synapse density and glial synaptic coverage in the hippocampus of adult offspring. Eur. J. Histochem. 2014, 58, 2355. [CrossRef] [PubMed]

53. Then, S.M.; Mazlan, M.; Top, G.M.; Ngah, W.Z.W. Is vitamin E toxic to neuron cells? Cell Mol. Neurobiol. 2009, 29, 485-496. [CrossRef] [PubMed]

54. Wang, C.; Youle, R.J. The role of mitochondria inapoptosis. Annu. Rev. Genet. 2009, 43, 95-118. [CrossRef] [PubMed]

55. Lu, K.W.; Chen, J.C.; Lai, T.Y.; Yang, J.S.; Weng, S.W.; Ma, Y.S.; Lin, H.Y.; Wu, R.S.; Wu, K.C.; Wood, W.G.; et al. Gypenosides suppress growth of human oral cancer SAS cells in vitro and in a murine xenograft model: The role of apoptosis mediated by caspase-dependent and caspase-independent pathways. Integr. Cancer Ther. 2012, 11, 129-140. [CrossRef] [PubMed]

56. Chan, J.Y.; Chang, A.Y.; Wang, L.L.; Ou, C.C.; Chan, S.H. Protein kinase C-dependent mitochondrial translocation of proapoptotic protein Bax on activation of inducible nitric oxide synthase in rostral ventrolateral medulla mediates cardiovascular depression during experimental endotoxemia. Mol. Pharmacol. 2007, 71, 1129-1139. [CrossRef] [PubMed]

57. Zhivotovsky, B.; Galluzzi, L.; Kepp, O.; Kroemer, G. Adenine nucleotide translocase: A component of the phylogenetically conserved cell death machinery. Cell Death Differ. 2009, 16, 1419-1425. [CrossRef] [PubMed]

58. Whelan, R.S.; Konstantinidis, K.; Wei, A.C.; Chen, Y.; Reyna, D.E.; Jha, S.; Yang, Y.; Calvert, J.W.; Lindsten, T.; Thompson, C.B.; et al. Bax regulates primary necrosisthrough mitochondrial dynamics. Proc. Natl. Acad. Sci. USA 2012, 109, 6566-6571. [CrossRef] [PubMed]

59. Kowaltowski, A.J.; Fiscum, G. Redox mechanisms of cytoprotection by Bcl-2. Antioxid. Redox Signal. 2005, 7, 508-514. [CrossRef] [PubMed]

60. Hsuan, S.L.; Klintworth, H.M.; Xia, Z. Basic fibroblast growth factor protects against rotenone-induced dopaminergic cell death through activation of extracellular signal-regulated kinases $1 / 2$ and phosphatidylinositol-3 kinase pathways. J. Neurosci. 2006, 26, 4481-4491. [CrossRef] [PubMed] 
61. Weinreb, O. Novel neuroprotective mechanism of action of rasagiline is associated with its propargyl moiety: Interaction of Bcl-2 family members with PKC pathway. Ann. N. Y. Acad. Sci. 2005, 1053, 348-355. [CrossRef] [PubMed]

62. Dichter, M.A. Rat cortical neurons in cell culture: Culture methods, cell morphology, electrophysiology, and synapse formation. Brain Res. 1978, 149, 279-293. [CrossRef]

63. Mironova, E.V.; Evstratova, A.A.; Antonov, S.M. A fluorescence vital assay for the recognition and quantification of excitotoxic cell death by necrosis and apoptosis using confocal microscopy on neurons in culture. J. Neurosci. Methods 2007, 163, 1-8. [CrossRef] [PubMed]

64. Dringen, R.; Kussmaul, L.; Hamprecht, B. Detoxification of exogenous hydrogen peroxide and organic hydroperoxides by cultured astroglial cells assessed by microtiter plate assay. Brain Res. Protoc. 1998, 2, 223-228. [CrossRef]

65. Nagasaki, H.; Nakashima, A.; Kaneko, Y.S.; Kodani, Y.; Takayanagi, T.; Itoh, M.; Kondo, K.; Nagatsu, T.; Hamada, Y.; Ota, M.; et al. Aripiprazole increases NADPH level in PC12 cells: The role of NADPH oxidase. J. Neural Transm. 2014, 121, 91-103. [CrossRef] [PubMed]

(C) 2017 by the authors; licensee MDPI, Basel, Switzerland. This article is an open access article distributed under the terms and conditions of the Creative Commons Attribution (CC BY) license (http:/ / creativecommons.org/licenses/by/4.0/). 